\title{
Review \\ The Role of Estrogen Receptors and Their Signaling across Psychiatric Disorders
}

\author{
Wu Jeong Hwang ${ }^{1}$, Tae Young Lee ${ }^{2,3, *}$, Nahrie Suk Kim ${ }^{2}$ and Jun Soo Kwon ${ }^{1,4} \mathbb{D}$ \\ 1 Department of Brain and Cognitive Sciences, College of Natural Sciences, Seoul National University, \\ Seoul 08826, Korea; hwj7942@gmail.com (W.J.H.); kwonjs@snu.ac.kr (J.S.K.) \\ 2 Department of Psychiatry, Pusan National University Yangsan Hospital, Yangsan 50612, Korea; \\ nahriekim@gmail.com \\ 3 Research Institute for Convergence of Biomedical Science and Technology, Pusan National University \\ Yangsan Hospital, Yangsan 50612, Korea \\ 4 Department of Psychiatry, Seoul National University College of Medicine, Seoul 03080, Korea \\ * Correspondence: leetaey@gmail.com; Tel.: +82-55-360-2468
}

Citation: Hwang, W.J.; Lee, T.Y.; Kim, N.S.; Kwon, J.S. The Role of Estrogen Receptors and Their Signaling across Psychiatric Disorders. Int. J. Mol. Sci. 2021, 22, 373. https://doi.org/ 10.3390/ijms 22010373

Received: 30 November 2020 Accepted: 28 December 2020 Published: 31 December 2020

Publisher's Note: MDPI stays neutral with regard to jurisdictional clai$\mathrm{ms}$ in published maps and institutional affiliations.

Copyright: $\odot 2020$ by the authors. Licensee MDPI, Basel, Switzerland. This article is an open access article distributed under the terms and conditions of the Creative Commons Attribution (CC BY) license (https:// creativecommons.org/licenses/by/ $4.0 /)$.

\begin{abstract}
Increasing evidence suggests estrogen and estrogen signaling pathway disturbances across psychiatric disorders. Estrogens are not only crucial in sexual maturation and reproduction but are also highly involved in a wide range of brain functions, such as cognition, memory, neurodevelopment, and neuroplasticity. To add more, the recent findings of its neuroprotective and antiinflammatory effects have grown interested in investigating its potential therapeutic use to psychiatric disorders. In this review, we analyze the emerging literature on estrogen receptors and psychiatric disorders in cellular, preclinical, and clinical studies. Specifically, we discuss the contribution of estrogen receptor and estrogen signaling to cognition and neuroprotection via mediating multiple neural systems, such as dopaminergic, serotonergic, and glutamatergic systems. Then, we assess their disruptions and their potential implications for pathophysiologies in psychiatric disorders. Further, in this review, current treatment strategies involving estrogen and estrogen signaling are evaluated to suggest a future direction in identifying novel treatment strategies in psychiatric disorders.
\end{abstract}

Keywords: estrogen; estrogen receptors; schizophrenia; bipolar disorder; major depression disorder; autism; attention-deficit/hyperactivity disorder; raloxifene; hypothalamic-pituitary-gonadal axis

\section{Introduction}

Globally, one in seven people (equivalent to $11-18 \%$ of the population) suffers from mental or substance use disorders [1]. Despite many efforts, the prevalence of mental disorders remains high, and interestingly, there exist gender disparities. Women have a higher prevalence than men [1]. Indeed, multiple psychiatric disorders display sex differences in their symptoms, age of onset, and prevalence. In general, males are more susceptible to neurodevelopmental disorders, including schizophrenia, autism spectrum disorder (ASD), and attention-deficit/hyperactivity disorder (ADHD), whereas females are more susceptible to depressive, anxiety, and eating disorders. Multiple factors, such as social and environmental factors, via various pathways and circuits in the brain, play a role in creating these sex differences. However, accumulated evidence suggests biological factors as one of the strongest candidates underlying this phenomenon and a closer examination of sex hormones-in particular, estrogen.

Estrogens have traditionally been known to have their effects on reproductive behaviors, such as sexual receptivity and maternal behaviors [2]. However, over the past twenty years of extensive research, both in animals and humans, it is now known that estrogens, via their signaling mechanisms and interactions with multiple neurotransmitter systems in our brain, including dopamine, serotonin, and glutamate, have heavy involvement in cognition and mood [3-5]. Recent investigations have revealed pronounced 
interactions of estrogens with the dopaminergic system, a highly implicated system in the pathophysiology of multiple psychiatric and neurodegenerative disorders, and that they modulate executive functions, such as working memory and reward processing [6-8]. Further, the roles of estrogen receptors and estrogen signaling have been highlighted, with studies reporting their neuroprotective effects on the brain by promoting neurotrophins synthesis and protecting the brain from inflammation and stress [9-11]. To add more, investigations revealed, in animal models of psychiatric disorders and in patients, that estrogen and estrogen signaling are disturbed and that they are associated with not only the cognitive deficits but, also, the manifestations of the symptoms, which could also be reversed with estrogen administration or treatments targeting estrogen-signaling pathways [11-13]. Thus, together with much evidence on estrogen signaling disruptions in psychiatric disorders, recently, their effects have been taken under examination in multiple clinical trials for the critical assessment and evaluation of their efficacy as a new treatment for psychiatric patients [14-18]. Altogether, accumulating evidence suggests that estrogen and estrogen signaling may be highly implicated in the pathophysiology of psychiatric disorders, warranting a comprehensive and integrated understanding of estrogen and estrogen signaling across multiple levels of the brain system architecture from cellular and molecular to systemic to elucidate the mechanisms involved in its therapeutic effects in psychiatric disorders.

In this review, we first describe estrogen receptor signaling by providing summarized information of the literature on estrogen receptor signaling; distributions of estrogen receptors in the brain; their mechanisms of actions on major neurotransmitters of our brain, including dopaminergic, serotonergic, and glutamatergic; and their cognitive and neuroprotective effects. Next, we critically assess the recent progress of our understanding of the role of estrogen receptor signaling and its therapeutic effects in psychiatric disorders, including schizophrenia, bipolar disorder, major depressive disorder (MDD), ASD, ADHD, general anxiety disorder (GAD), post-traumatic stress disorder (PTSD), eating disorders, and substance use disorder, with an aim to provide and highlight the importance of estrogen singling in major psychiatric disorders, thereby possibly providing guidance as to finding new therapeutic targets.

\section{Estrogen Receptor Signaling}

\subsection{Estrogen}

The estrogen family is a steroid hormone and consists of one benzene ring, a phenolic hydroxyl group, and a ketone group, and, depending on the number of hydroxyl groups, the estrogens are named estrone (zero groups, E1), estradiol (one group, E2), estriol (two groups, E3), and estetrol (three groups, E4). While females produce estrogens all during their lives, however, for the predominance during the reproductive years and high relevance to physiology, the word estrogen in the literature commonly refers to E2 (or $17 \beta$-estradiol). Estrogens have been traditionally reported to have physiological functions involved in the development of breast tissue and sexual organs, regulations of the menstrual cycle and reproduction, and maintenance of our bone density. However, recent reports suggest its cognitive $[3,19]$ and neuroprotective effects [10] and anti-inflammatory roles [20]. Estrogens are also present in males at low levels [21], and in men, they are involved in reproduction, such as spermatogenesis, erectile function, and libido [22]. Estrogens are produced primarily in ovaries from testosterone but can also be produced in the liver, adipose tissue, heart, and, most importantly, the brain [23]. In the brain, there exists regional specifics in estrogen production, suggesting their selective involvement of the brain functions. Reports show that estrogens are produced in the hippocampus, cerebellum, hypothalamus, amygdala, and cortex [24] by neurons and astrocytes [25].

\subsection{Estrogen Receptors and Their Signaling Mechanisms}

Estrogens exert their effects via estrogen receptors. There currently are three known classes of receptors, estrogen receptor alpha $(E R \alpha)$, estrogen receptor beta $(E R \beta)$, and $G$ 
protein-coupled receptor 30 (GPER). With GPER being relatively recently discovered [26], $E R \alpha$ and $E R \beta$ are the most widely studied in the literature. ER $\alpha$ and ER $\beta$ are composed of various functional domains and have several structural regions in common, the aminoterminal domain (NTD) and estrogen response elements (ERE). Since estrogens are steroid hormones, they can exert their direct effects by entering the plasma membrane and taking estrogen receptor complexes to the cell nucleus and interacting and binding directly onto the ERE of intracellular ER $\alpha$ and ER $\beta$. Otherwise, they can indirectly exert their effects by activating intracellular signaling cascades via interacting with estrogen receptors. Thus, estrogen signaling can be divided into genomic (direct binding onto ERE) and nongenomic (activation of an intracellular signaling cascade). Recent reports suggest that 35\% of genes that are regulated by estrogen receptors lack EREs, in which only nongenomic estrogen signaling can be conducted [27]. There exist multiple signal transduction pathways in response to estrogen, and the same estrogen binding can lead to different, or even opposite [28,29], responses in ER $\alpha$ and ER $\beta$ (See Fuentes et al., 2019 [30] for a detailed review). Generally, ER $\alpha$ is known to modulate neurobiological reproductive systems, such as those involved in sexual characteristics and puberty. ER $\beta$ is known to be involved in the modulation of nonreproductive systems, such as anxiety, locomotion, fear, and memory and learning.

\subsection{Estrogen Receptors in the Brain}

Along with estrogens, ER $\alpha$ and ER $\beta$ are widely distributed in our brain, including the hippocampus, hypothalamus, amygdala, thalamic connectivity system regions [31] of the thalamus, cerebellum, and cortex, as well as the cortico-striato-thalamo-cortical (CSTC) circuit-related regions of the basal ganglia and striatum. GPERs are also expressed in the hippocampus, cortex, and hypothalamus [32]. Revealed by extensive neuroimaging studies, interestingly, these areas are the most frequently reported regions of deficits in psychiatric patients, and below, we provide a brief description of estrogen receptor distributions.

The receptors possess different dominance in different brain regions (Figure 1). Describing the distribution in all brain regions may be unpractical for this article. However, to provide a brief description, in the cortex, ER $\alpha$ and ER $\beta$ are present particularly at the prefrontal and temporal cortexes in humans. In rats, reports show the existence of ER $\alpha$ in the medial prefrontal cortex [33] and the colocalization of ER $\alpha$ and ER $\beta$ in sensorimotor areas [34], with the density of ER $\beta$ being greater than that of ER $\alpha$ [35]. In the temporal cortex of humans, a report showed a higher density of ER $\alpha$ in the nuclei and ER $\beta$ in the cytoplasm [36]. In the hippocampus, the pivotal region of the cognitive functioning of learning and memory in our brain, ER $\beta$ is expressed at moderately high levels at the regions of the subiculum, cornu ammonis 1-2 (CA1-CA2), and CA3 dentate gyrus $[35,37,38]$ and is a primary regulator of the region in both rats and humans. In the amygdala, $\mathrm{ER} \alpha$ is the primary regulator of the region; thus, they are predominantly expressed [39]. In humans, $\mathrm{ER} \alpha$ is found the highest at the periamygdala cortex, amygdala-hippocampal area, and posterior cortical nucleus [37,40]. The co-expression of both receptors is the highest at the medial posterior-dorsal nucleus [39]. ER $\alpha$ is also a primary regulator of the hypothalamus. In humans, the ER $\alpha$ is expressed the highest at the supraoptic, paraventricular, arcuate, and periventricular nuclei [37]. The regions both ER $\alpha$ and ER $\beta$ are co-expressed, although beta is expressed at low levels, at the supraoptic, paraventricular, arcuate, and ventromedial nuclei [37]. The expression of ER $\alpha$ and ER $\beta$ are found in the major node of the CSTC circuit in our brain, the basal ganglia, where also dopamine cell bodies reside. Reports show the expression of estrogen receptors in dopamine neurons in rodents $[35,41]$ and even the modulation of dopamine neurotransmission by estrogen [42-44]. In rodents, reports have found ER $\alpha$ and ER $\beta$ expressions in the striatum, with estrogen receptors being expressed low at the nuclei and high at the extracellular sites [45]. However, ER $\alpha$ and ER $\beta$ expressions have not, so far, been detected in the human striatum [40]. Further evidence of ER $\alpha$ and ER $\beta$ exists in the center node of the thalamic connectivity system: the thalamus and the cerebellum. Both regions are primarily regulated 
by ER $\beta$ [46]. In the thalamus, in humans, low levels of ER $\beta$ are found in the paratenial and paraventricular nuclei, and ER $\alpha$ is found in the posterior nuclei only [47]. Interestingly, sex differences in these areas have been shown, with men expressing a higher density of nuclear ER $\beta$ receptors than women [47].

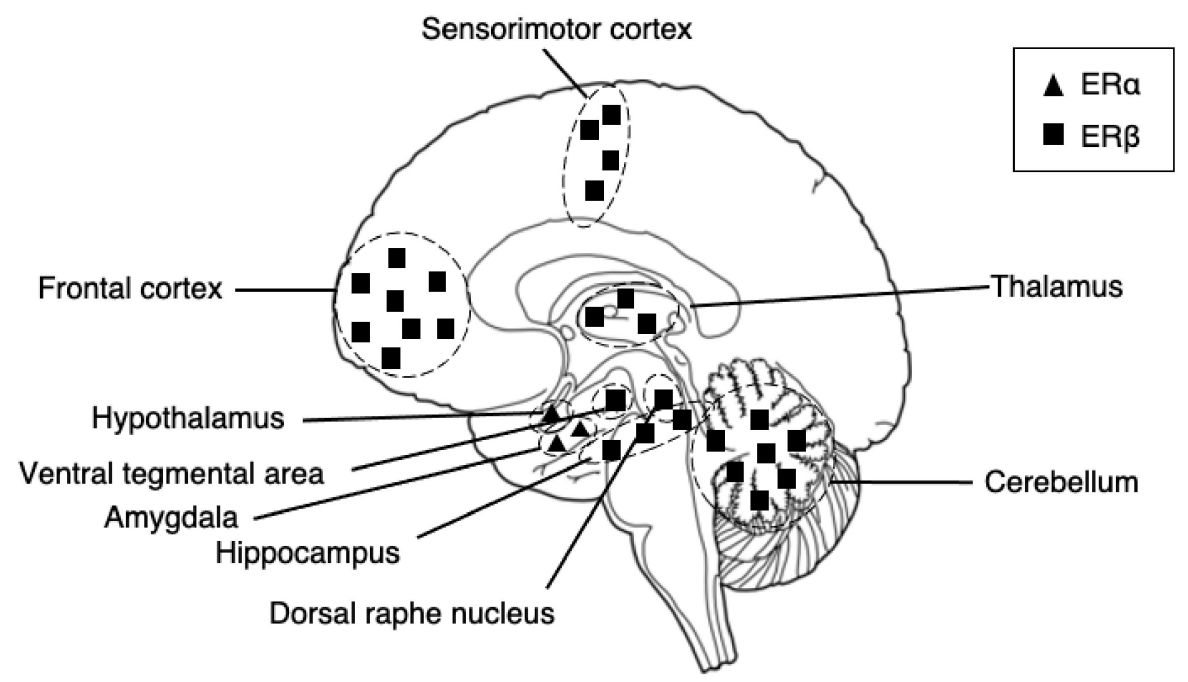

Figure 1. A schematic diagram of distributions of estrogen receptor alpha and estrogen receptor beta in our brains. The receptors have a different predominance of expression in distinct regions. $\mathrm{ER} \alpha$ is predominantly expressed in the amygdala and hypothalamus, whereas ER $\beta$ is predominantly expressed in the somatosensory cortex, hippocampus, thalamus, and cerebellum.

\subsection{Mechanism of Actions on Neurotransmitter Systems}

Mounting evidence from both clinical and preclinical studies suggests the modulation of estrogen, via estrogen receptor signaling, on neurotransmitter systems in our brains, such as dopaminergic, serotonergic, and glutamatergic, the key neurotransmitter systems implicated in major psychiatric disorders. Estrogens exert effects on neurotransmitter systems by targeting and regulating the expressions of specific subtypes of neurotransmitter system receptors in a region-specific manner, contributing to our cognition, mood, and behavioral responses. For example, estrogens present selectivity in exerting effects on serotonin receptor subtypes that have high implications to cognitive functions commonly disrupted across multiple psychiatric disorders, such as learning, memory, and cognitive flexibility [48,49]. Mounting reports suggest a strong modulatory effect of estrogen on major neurotransmitter systems in our brain, and extensive studies have found neuroleptic-like properties of estrogen [15] similar to atypical antipsychotics used in psychiatric disorders on dopaminergic, serotonergic, and glutamatergic systems. Thus, a better understanding of the nature of these interactions is suggested for assessing the therapeutic potential of estrogen. To maintain the scope of this article, brief descriptions will be provided in this article, but we recommend Krolick and her colleagues for a detailed review of the interactions [50].

Preclinical studies have extensively revealed many profound yet complex effects of estrogens on dopaminergic neurotransmissions [42]. Briefly, the current literature reports that (1) estrogens increase dopamine synthesis in the nucleus accumbens, induce presynaptic dopamine release in the striatum, and decrease the turnover in the nucleus accumbens [51-56]. (2) Evidence suggests the regulation of D1 and D2 receptor densities and functions by estrogens [57-60]. (3) Estrogens prolong neurotransmissions by reducing dopamine transporters in the nucleus accumbens [61-63]. Similarly, extensive studies report the effects of estrogens on the serotonergic neurotransmission system. Specifically, current evidence suggests that (1) estrogens upregulate the expression and activity of TPH to increase 5 HT biosynthesis $[51,64]$ and (2) regulate 5HT receptors 5HT2A and $2 \mathrm{C}$, the receptors of which have high implications in depression [65-70]. (3) Estrogens 
regulate $5 \mathrm{HT}$ autoinhibition via the $5 \mathrm{HT} 1 \mathrm{~A}$ auto-receptor, resulting in an antidepressantlike activity [71]. (4) Estrogen treatments reduce the 5HT uptake to presynaptic cells and prolong neurotransmissions [72]. (5) Estrogens decrease 5HT metabolism via degradation by monoamine oxidase inhibitors (MAO) after $5 \mathrm{HT}$ is taken up into the presynaptic neurons $[68,73,74]$. It has also been shown that estrogens exert their effects on the glutamatergic neurotransmitter system, which facilitates most of our neurotransmissions in our brain and mediates our cognitive functions. Current reports suggest that estrogens affect N-Methyl-D-aspartic acid (NMDA) glutamate receptors and upregulate and increase their distributions [75-77]. Notably, reports revealed the neuroprotective effects of estrogen on cortical and hippocampal neurons against the effects of glutamate-mediated neurotoxicity $[78,79]$.

\subsection{Estrogen Receptors and Cognition}

Extensive reports depict the effects of estrogens on cognition. In humans, it has been reported that verbal memory impairments and menopause-related cognitive decline can be rescued by estradiol replacement therapy $[80,81]$. Studies have been reporting varying the results of outcomes of estradiol replacement therapy, depending on the dosage, duration, and type of the treatment; however, in general, estrogens have beneficial impacts on cognitive functioning [81]. Finer details of the relationship have been thoroughly investigated in preclinical studies. Studies have reported the distinguished characteristics of estrogen receptors; ER $\beta$ knockout mice show severely disruptive behaviors in memory and learning [82], and ER $\alpha$ knockout mice show severe deficits in reproduction [83]. Further, their distributions and expressions in our brain regions converge onto most cognitively relevant brain regions, and, via estrogen signaling, they also exert effects on the synaptic formation [84]. For example, in a recent study, it was reported that ER $\beta$ plays a crucial role in motor learning in the cerebellum by potentiating the neuronal plasticity and synaptogenesis in that brain region [85].

Extensive reports suggest the particular involvement of estrogen on the working memory $[86,87]$. In an ovariectomy performed on rodents, both spatial and nonspatial working memory deficits were observed, and the estradiol treatment also rescued those deficits [88]. In humans, high estradiol levels during menstrual phases in healthy women and estrogen replacement therapy (ERT) in postmenopausal women have been shown to improve the spatial working memory $[89,90]$. Their notable actions on the hippocampus and prefrontal cortex, in particular, have also been reported. It has been reported, in rodents, that exogenous estradiol administration reverses the decreases in the dendritic spine density of neurons in the hippocampus and prefrontal cortex caused by an ovariectomy, as well as improving the memory [91-93]. The detailed actions are yet to be thoroughly elucidated; however, their receptor distributions are wide across brains, and complex interactions with multiple neurotransmitter systems, as described in previous sections, conveniently place them as a key player in cognitive functioning.

\section{Beneficial Effects of Selective Estrogen Receptor Modulators (SERMs) on Cognition}

Estrogen signaling and its effects on cognition are particularly relevant to psychiatric disorders, as they display global cognitive deficits; particularly the disorders possess different degrees of executive dysfunctions [94,95]. Nonetheless, despite vigorous effort, the currently available pharmaceutical treatments for psychiatric disordersparticularly, schizophrenia-do not show satisfactory results in treating the cognitive deficits. In schizophrenia, despite the cognitive deficits being related to the patient's functional impairment, there exist mixed results in pharmaceutical treatments for cognitive deficits $[96,97]$. The alpha-7-nicotinic receptor agonist has shown significant beneficial effects with small effect sizes on the CogState battery $[98,99]$. However, both the alpha-7nicotinic receptor agonist and modafinil have been found insignificant on the Measurement and Treatment Research to Improve Cognition in Schizophrenia $[100,101]$. Thus, currently, 
it is very urgent to identify novel pharmacological targets, and amongst many targets, estrogenic treatments have been showing highly promising results.

ERTs, which have beneficial effects on the domains of verbal memory, speech, abstract reasoning, and information processing in postmenopausal women, come with the side effects of increased risks of thromboembolism, hot flashes, and breast hyperplasia when used long term, and most importantly, the therapy is prohibited for use in men due to feminizing effects [102]. Thus, recent studies have been focusing on another class of drugs that act on the estrogen receptor, selective estrogen receptor modulators (SERMs), which have antagonistic effects in the breasts and uterus and agonistic effects in the bone and brain. There are two classes of SERMs: triphenylethylene, which includes tamoxifen, clomiphene, toremifene, and GW5407, and benzothiophene, which includes raloxifene, arzoxifene, bazedoxifene, and lasofoxifene. Each has different properties and treatment effects, depending on the estrogen receptor subtypes, coactivators, and corepressors in the brain region. Reports show SERMs interact with $\operatorname{ER} \alpha, \operatorname{Er} \beta$, and, also, GPER and can activate both genomic and nongenomic cascades, such as cAMP/PKA, MAPK/ERKs, PI3K/Akt, and Wnt/ $\beta$-catenin, which are major signaling pathways in our brain for cognition and neuroprotection [103-105]. However, different SERMs, for their distinct properties, result in different actions in our brains. For example, tamoxifen, a first-generation SERM initially developed for the treatment of breast cancer, and raloxifene have shown a similar affinity for both ER $\alpha$ and ER $\beta$, whereas raloxifene, a second-generation SERM developed for osteoporosis treatment, has a four-times higher affinity for ER $\alpha$ [106]. Thus, unlike their initial developmental purposes, studies found beneficial effects in cognition-particularly in the memory - as well as neuroprotective and antioxidizing effects in SERMs, both in healthy and injured brains [85,107-110]. Raloxifene, in particular, has been reported, via various cell signaling cascades, to regulate plasticity; improve memory; and exert neuroprotective, antioxidative, and anti-inflammatory effects $[85,107,108]$. Therefore, multiple clinical trials assessing their efficacies and effects on cognition have been conducted across multiple psychiatric disorders, described in the following sections.

\subsection{Estrogen and Its Neuroprotective Effects}

Converging lines of evidence report that estrogens, via estrogen signaling, are implicated in neuroprotection $[111,112]$. Evidence suggests their implications in synaptic plasticity, antioxidative effects, apoptosis, and protection against excitotoxicity [113-116]. Reports also have shown estrogens facilitate glucose metabolism by having a regulatory role in the cerebral blood flow and can enhance the electron transport chain activity to provide more energy to neurons [117].

Further, estrogens provide neuroprotection by having anti-inflammatory effects $[118,119]$. They regulate and promote the synthesis of neurotrophins, such as brain-derived neurotrophic factor (BDNF), which is a highly implicated molecule to various psychiatric disorders for its pertinent roles in neuronal survival, differentiation, and synaptic plasticity [120]. Further, reports have shown that ER $\alpha$ and ER $\beta$ have regulatory roles in the production of proinflammatory cytokines and chemokines and that this can occur either through estrogen-dependent or -independent mechanisms [121]. However, there exist "critical periods" for estrogens to exert their neuroprotective effects. It has been reported that estrogen therapies need to be given immediately after brain injuries, as the treatment loses the effect when given ten weeks post-ovariectomy [122]. In the same study, long-term estrogen deprivation caused a reduction in ER $\alpha$ receptors in the hippocampus, and the "critical period" is suggested to be due to tissue-specific reductions of estrogen receptors [122].

\section{Estrogen Receptor and Psychiatric Disorders}

\subsection{Schizophrenia}

Schizophrenia is a severely debilitating disorder that affects $1 \%$ of the population. It has, largely, three symptom domains of positive symptoms, negative symptoms, and cog- 
nitive deficits. Sex differences in the pathophysiology are well-documented in the literature. Compared to women, in males, evidence shows higher incidence rates, early-onset, and different symptoms [123]. Men have earlier onset and higher incidence rates of the disorder than women, as well as present more symptoms of conduct disorders, aggression, antisocial personality traits, and higher levels of psychopathology. Women have a higher incidence of negative symptoms, substance abuse, and depression. Further, there exist differences in the number of peaks in the age of onset between the sexes. Men have a single peak between 21 and 25 years of age, and women have two, the first after menarche and the second postmenopause [124]. This has led to the "estrogen hypothesis" in schizophrenia, which posits that estrogens provide neuroprotective effects against the disorder in regards to the onset, progression, and symptom severity, as well as the promotion of healthy brain development [125-127].

Studies revealed and confirmed detailed correlations between estrogen levels and schizophrenia symptoms. Low plasma estrogen levels have been correlated with increased risks for schizophrenia symptoms in women [128], and estrogen levels across the menstrual cycle have been inversely correlated with psychopathological symptoms in women with schizophrenia [129]. Menstrual cycle irregularities in schizophrenia patients have also been reported to be a predictor of lower cognitive performance in areas of psychomotor speed, verbal fluency, and verbal memory, suggesting that cognitive deficits in schizophrenia are partly attributed to estrogens [130]. During pregnancy, when in the surge of estrogen levels, patients have shown low rates of relapse of the disorder [131]. Studies also have found that the early timing of menarche has beneficial effects in providing neuroprotective effects against psychosis deterioration [132], and a recent neuroimaging study revealed that an earlier age at menarche (i.e., earlier availability of estrogens) results in more normative hippocampal connectivity in high risk for psychosis youths [133]. A study also suggested the neuroprotective role of estrogen in reducing symptom severity and susceptibility [134].

Studies have also revealed the effects of estrogens on cognitive deficits seen in schizophrenia patients. Both in healthy populations and in schizophrenia patients, studies have shown that estrogen levels correlate with well-being and cognitive functioning. Further, reports have demonstrated low estradiol phases are associated with poorer verbal and spatial memory, as well as perceptual-motor speed [135]. A neuroimaging study using functional magnetic resonance imaging (fMRI) also reported that there is a significant positive correlation between sex steroid levels and brain activity in both female schizophrenia patients and healthy males [136]. In preclinical studies, using rodent models of schizophrenia, a few studies have examined the molecular and genetic details of such cognitive disruptions seen in patients. The studies yielded promising results that estrogens can be used to ameliorate working memory deficits. Different models exist, but most tried to implement the cognitive deficits observed in schizophrenia by manipulating the NMDA receptors. Celia Moreira Borella and colleagues [137] reported working memory and prepulse inhibition (PPI) deficits when estrogen levels are the lowest and normal behaviors when the levels are the highest in a model using a neonatal N-Methyl-D-aspartic acid receptor (NMDAR) blockade with ketamine. Gogos and colleagues [138,139] reported the effects of estrogen or selective estrogen receptor modulators on PPI deficits caused by MK801 or apomorphine in ovariectomized rats. Further, in a recent study, Gogos and colleagues [140] reported that chronic treatment with estrogens reversed the PPI disruptions and the increased dopamine D2 receptor-binding densities in Poly(I:C)-treated rodents, suggesting that the beneficial effects may be mediated by selective changes in densities of dopamine $\mathrm{D} 2$ receptors.

Mounting evidence exists reporting subnormal estrogen levels in both treated and untreated schizophrenia patients and high risk for psychosis subjects [136,141,142]. In addition to the aforementioned deficits observed peripherally, studies exist reporting alterations in the brain's response to these hormones. It has been reported that both men and women with schizophrenia have reduced mRNA levels of ER $\alpha$ in the hippocampus [143]. The $\mathrm{ER} \alpha$ gene and its mRNA expression has further been reported to be associated with 
schizophrenia [144]. Further, reports have also shown that women with schizophrenia often are hypoestrogenic, and converging evidence suggests this may be the consequential effect of hyperprolactinemia, a common side effect of antipsychotic mediation [145]. It has been suggested that, as increased levels of prolactin suppress the hypothalamic-pituitarygonadal (HPG) axis in a negative feedback manner, estrogen and testosterone levels become decreased, resulting in hypoestrogenism observed in schizophrenia patients. However, recent lines of investigation revealed that hyperprolactinemia alone cannot be a full explaining factor of hypoestrogenism in schizophrenia [146] and that hyperprolactinemia is also independent of antipsychotics [147-150] (see Du and Hill, 2019 for a detailed review [151]).

Thus, currently, clinical trials are being conducted to test estrogen as a new target of therapy. Initially, studies focused on rescuing the estrogen level itself. The direct administration of estrogens showed improvements in the speech comprehension of female schizophrenia patients [152]. Transdermal estradiol patch therapy also demonstrated beneficial effects and significantly improved the psychotic symptoms in female patients with schizophrenia; however, no positive effects were found in their cognitive functioning [153]. Recent research paradigms have shifted towards assessing SERMs-in particular, raloxifene-on symptom amelioration and cognition enhancements in schizophrenia patients for their lack of sensitization and feminization and selective action as potent estrogens only in the bone and brain.

Raloxifene has shown promising results in the improvement of the cognitive impairment-particularly, attention, memory, and learning-seen in schizophrenia. Further, raloxifene improves symptoms in schizophrenia patients. Recent studies have found that raloxifene improves both positive and negative symptoms in women and negative symptoms in men [11]. Its effects were also assessed in multiple clinical trials in which its beneficial effects on multiple domains of executive functions and psychopathology were confirmed in various subgroups of schizophrenia patients, such as men and women with schizophrenia, treatment-resistant young women with schizophrenia, and postmenopausal women with schizophrenia [154-157]. Further, in one study, the beneficial effects were maintained even when the dose was reduced to half $[156,158]$. However, more studies are needed to elucidate the mechanisms of raloxifene, and the current literature shows varying degrees of improvements by raloxifene on cognition and psychopathology, suggesting further clinical trials.

\subsection{Bipolar Disorder}

Bipolar disorder is characterized by cycles of mania and depression. The disorder can be classified into Bipolar I disorder, which is characterized by much severer mood episodes, from mania to depression, and Bipolar II disorder, which is characterized by milder episodes of hypomania and alternate with severe depression. There exist gender differences in the disorder in that women present with symptoms later in life than men and have faster cycling of mania and depression than men (Table 1). Gender differences are also seen amongst the subtypes. Bipolar II disorder is more common in women than men. Numerous reports show that women with bipolar disorder, during periods of hormonal fluctuation, are associated with increased vulnerability to developing depression and increased risk of affective dysregulation.

Increased levels of GPER-1 were recently reported in euthymic outpatients of bipolar disorder, the results of which were not influenced by medications [159]. So far, the two studies that have examined the relationship between $\operatorname{ER} \alpha, \mathrm{ER} \beta$, and bipolar disorder have found negative results $[160,161]$, unlike in schizophrenia. Despite there being a limited number of studies examining the associations between estrogens and estrogen receptors in bipolar disorder, reports show high associations between the symptomatic course in patients with bipolar disorder and the periods of hormonal fluctuations. It has been reported that bipolar disorder patients who experience premenstrual exacerbation are more likely to have a worse course of illness, a shorter time to relapse, and increased severity in their symptoms [162]. Further, in a recent study, the bipolar patients who report 
reproductive cycle event-related worsening of their mood were associated with rapid cycling, comorbid anxiety, and mixed mood episodes [163]. Taken together, the current lines of evidence show that disruptions in estrogen and estrogen signaling and estrogen fluctuations are associated with the symptoms.

Table 1. Gender and hormonal effects across psychiatric illnesses.

\begin{tabular}{|c|c|c|c|}
\hline & Prevalence(Male:Female) & Menstrual Cycle Effects & Effects of Menopause \\
\hline Schizophrenia & $1.4: 1$ & $\uparrow$ sx in low hormone phase & $\uparrow \mathrm{sx}, \uparrow$ prevalence \\
\hline Bipolar disorder & $1: 1$ & $\uparrow$ sx in low hormone phase & $\uparrow s x$ \\
\hline MDD & 1:1.6 & $\uparrow$ sx in low hormone phase & $\uparrow s x, \uparrow$ prevalence \\
\hline ASD & $1: 4$ & $\uparrow$ sx in low hormone phase & $\uparrow s x$ \\
\hline ADHD & $1: 2$ & $\uparrow$ sx in low hormone phase & $\uparrow \mathrm{sx}, \uparrow$ prevalence \\
\hline GAD & $2: 1$ & $\uparrow$ sx in low hormone phase & $\uparrow \mathrm{sx}, \uparrow$ prevalence \\
\hline PTSD & $2: 1$ & $\uparrow$ sx in low hormone phase & $\uparrow$ prevalence \\
\hline Eating disorder & 3 to 10 times in women & $\begin{array}{c}\uparrow \text { sx in low hormone phase in } \\
\text { bulimia,N/A in anorexia }\end{array}$ & $\uparrow \mathrm{sx}, \uparrow$ prevalence \\
\hline Substance use disorder & $1: 2$ & $\begin{array}{c}\text { Reinforcing effects of } \\
\text { stimulants (Estrogen, } \\
\uparrow ; \text { Progesterone, } \downarrow \text { ) }\end{array}$ & $\uparrow$ prevalence in alcohol abuse \\
\hline
\end{tabular}

Major depressive disorder (MDD); Autism spectrum disorder (ASD); Attention-deficit/hyeractivity disorder (ADHD); General anxiety disorder (GAD); Post traumatic stress disorder (PTSD); Symptom (Sx); Not available (N/A); Increase ( $\uparrow$ ); Decrease $(\downarrow)$.

Several clinical trials on SERMs have been showing promising effects in the treatment of bipolar disorder. Tamoxifen has been shown to have effects in reducing mania and depression when used together with a lithium treatment in children and adolescents with acute mania [164]. The study also reported the high efficacy of tamoxifen despite the small sample size. In a meta-study, tamoxifen adjuvant therapy was reported to reduce the frequency of manic episodes in bipolar patients [165]. However, tamoxifen is known to have side effects of thromboembolic events and increasing risks of endometrial cancer. Thus, efforts have been put into understanding and elucidating the detailed mechanisms of the actions of the drug. Animal studies have reported that the beneficial effects of tamoxifen on mania from the coadministration of lithium and tamoxifen come partly from lithium and tamoxifen changing the protein kinase $C$ signaling pathway [166]. The current literature, however, lacks the long-term effects of tamoxifen, and further studies are warranted.

\section{3. $M D D$}

MDD can be chronic or recurrent, and its impacts on mood and behavior are associated with poor health and mortality. Gender differences exist in MDD, like other psychiatric disorders, and women have a higher prevalence than men.

It is speculated, with multiple lines of evidence, that alterations in hormones play a crucial role in the pathophysiology of the disorder. Reports show high associations between the symptomatic course in patients with MDD and the periods of hormonal fluctuations. The patients, when in periods of ovarian hormone withdrawal, such as a postpartum period or menopause, have increased risks of mood symptoms and the occurrence of MDD [167]. At a molecular level, the GPER level has been reported to be elevated in MDD compared to healthy subjects, which also correlated with depression scores [168]. Using the data from one million Danish women, oral contraceptive uses were associated with an increased risk of a depression diagnosis, antidepressant treatments, and suicidal acts $[169,170]$. Further elucidation into detailed mechanisms involved in such a phenomenon was made in animal studies. During low-estradiol times of the cycles, rodents showed more profound depressive-like behaviors [171]. Further, ovariectomy caused an enhanced feeling of despair and was rescued with the estradiol administration in rodents [172].

ERTs are currently used to treat peri- or post-MDD patients. However, currently available clinical trials examining moods in pre- and postmenopausal women treated with 
hormone replacement have yielded mixed results for wide variations in the symptomatology of recruited samples and treatment timing postmenopause across studies [17]. It was revealed in a study that the early treatment of ERT has a cardioprotective effect, whereas the same treatment when treated 10 years after menopause exerted risk-enhancing effects [173].

\section{4. $A S D$}

ASD is a neurodevelopmental disorder that begins early in childhood. The disorder is characterized by dysfunctions in communicating and interacting with others, as well as learning disabilities. With the prevalence ratio of 4:1, men are more highly likely to develop this disorder [174]. Reports have long been made for the association between ASD development and increased testosterone exposure during pregnancy [175]. Studies associate testosterone levels to various symptoms and cognitive deficits manifested in ASD, such as social anxiety and reduced empathy, as well as deficits in social and language developments in ASD patients [68,176]. These led to the "extreme male brain" (EBM) theory [177], which proposes that ASD patients, due to elevated prenatal testosterone levels, can be considered as having an extreme of the normal male profile for their cognition and show a strong predominance of systemizing over empathizing.

The literature also describes estrogen-signaling disruptions in ASD. Aromatase, CYP19A1, which converts testosterone to estradiol, as well as estrogen and estrogen receptors, are reported to be decreased in ASD patients [178-180]. There exist significant associations between the ER $\beta$ gene and autism trait, measured by the Autism Spectrum Quotient and the Empathy Quotient in ASD patients [180]. Further, in a recent study, $E R \beta m R N A$ and protein levels were reported to be reduced at the middle frontal gyrus in the postmortem brains of ASD subjects. In the same study, ER coactivators were also reported to be disrupted in ASD. There were impairments in the steroid receptor coactivator1, CREB-Binding Protein (CBP), and P/mRNA levels in ASD patients [179]. With recent studies reporting disruptions in estrogen and estrogen signaling in ASD, thus, it may potentially be that abnormal levels of testosterone and the testosterone-associated cognitive deficits and symptoms may be representing one of the factors of ASD risk. Put together, the consideration of both testosterone and estrogen, for their close relationship, may benefit identifying the risk factors of ASD.

\section{5. $A D H D$}

ADHD is a neurodevelopmental disorder characterized by marked deficits in attention, hyperactivity, and impulsivity. Gender disparities in this disorder include males having twice as likely prevalence than females and ADHD females having increased inattentive symptoms than males [181], although the underlying factors are not well-elucidated.

Despite the associations between ADHD and estrogen signaling remaining relatively unexplored yet, a few case studies support the association. ADHD symptoms exacerbate a week before menstruation and become alleviated during pregnancy [182]. A recent study investigating serum estrogen and GPER levels in children with ADHD reported comparable serum estrogen levels but reduced GPER in ADHD children [183]. Much literature lies in the investigation of bisphenol A (BPA). BPA is a xenoestrogen compound that binds to estrogen receptors and affects the downstream cell signaling cascade [184]. Evidence supports associations between BPA and ADHD-like symptoms, occurring via disrupting multiple neurotransmitter systems of catecholaminergic, dopaminergic, and serotonergic signaling systems $[185,186]$. It has shown effects in behavioral outcomes in ADHD children when used in high doses [187]. Further, a study reported a significant positive association between BPA exposure and ADHD risk at four years of age, although the effect disappeared by seven years of age [187]. A recent meta-analysis examined the prenatal exposure to BPA in ADHD children and rodent models. Early BPA exposure was associated with increased hyperactivity in male rodents and both males and females in humans [188]. Given the contribution of estrogen to executive function, a possible marker of ADHD, 
the current literature warrants further studies exploring the contributions of estrogen in ADHD pathophysiology.

\subsection{Anxiety Disorders}

\subsubsection{Generalized Anxiety Disorder (GAD)}

GAD is characterized by excessive, ongoing anxiety and worry that interferes with daily functioning. The disorder is twice more prevalent amongst women than men [189], and interestingly, it is developed and manifested after puberty [190], suggesting contributing roles of hormones-particularly, estrogen - to the disorder pathophysiology.

Indeed, studies report disruptions of estrogen signaling in GAD. A study reported increased GPER levels in GAD, which further correlated with the anxiety severity in patients irrespective of gender [191]. In rodents, GPER-deficient rats showed anxiety-like behaviors, as well as low corticosterone [192]. Interestingly, reports show ER $\beta$ signaling has anxiolytic effects [193], and in mice, ER $\beta$ deficiency has been associated with social and mood-related behavioral disturbances via the oxytocin and arginine-vasopressin signaling pathways [194]. A recent report investigated interactions with the glutamatergic system and estrogen and showed that, for the estrogen mitigation of anxiety-related behaviors in rats, mGlu5 activation is necessary [195].

\subsubsection{PTSD}

PTSD is developed after experiencing a traumatic event and is characterized by severe anxiety, flashbacks, and nightmares of the trauma. Women have a twice-higher prevalence of the disorder than men following trauma [196]. Further, a meta-analytic study of 48 studies reported women to have better treatment responses than men [197]. Although the characteristics of the traumatic events may be different amongst the genders (e.g., women experience a greater number of interpersonal and sexual violence events, while men experience a greater number of industrial accidents and war), these are not completely explanative of the disparities. Recent studies suggest a high involvement of sex hormones-particularly, estrogen - in the pathophysiology and treatment of PTSD $[198,199]$.

Reports have shown that PSTD symptoms fluctuate with estrogen levels. One study reported increased phobic anxiety and depression at cycles of low estrogen levels [200]. Multiple genetic studies further support the implications of estrogen signaling in PTSD. The pituitary adenylate cyclase-activating peptide receptor gene has been reported to be associated with PSTD symptom severity in women but not men [201]. DNA methylation of the histone deacetylase 4 (HDAC4) gene, which is estrogen-dependent, is associated with fear learning and memory in PTSD [202]. It has also identified the implications of the ER $\alpha$ genes rs2234639 and rs9340799 in PTSD $[203,204]$. Recently, a neuroimaging study, using functional magnetic resonance imaging, administered blocks of the fear condition and extinction training to PTSD patients and measured their responses to fear with a skin conductance response. The study revealed the modulatory role of estrogens in PTSD severity and the arousal response, such that higher estrogens have protective effects against the negative impacts of PTSD symptoms [205]. This evidence, taken together, suggests a promising outlook towards using estrogen or the estrogen-signaling pathway as a putative pharmacological adjunctive treatment [199].

\subsection{Eating Disorders}

Eating disorders comprise the development of unhealthy eating habits due to psychological conditions. There exist gender disparities in the disorders, in that females have 3-10 times higher prevalence than men [206]. Sociocultural factors, indeed, are a significant factor driving the huge disparity; however, animal studies have shown pronounced differences in the disorder phenotypes occurring during puberty, supporting a big part of the biological factors-particularly, hormones-contributing to the disorder pathophysiology $[207,208]$. 
Preclinical studies have revealed that perinatal exposure to testosterone causes the sexual differences in behaviors of food intake, as well as the preference for sweet tastes [209]. In a study where the genetic influences on binge eating in girls were examined, it was found that girls with relatively high estrogen levels had minimal genetic influences of binge eating. On the other hand, girls with relatively low estrogen levels have greater genetic influences on binge eating [210], suggesting a protective role of estrogen against the genetically-mediated eating disorder. Further, genetics studies have identified risk the genes for an eating disorder. The ER $\alpha$ gene has been identified as being associated with an eating disorder, and a study reported that the decreased gene activity increased the risk of developing an eating disorder [211]. Further, the HDAC4 gene, of which DNA methylation is dependent on estrogen, was found also associated with eating disorders by changing feeding behaviors in mice [211]. Nonetheless, the pharmacological treatments for eating disorders, including estrogen or estrogen signaling target treatments, have, so far, been underexplored [212].

\subsection{Substance Use Disorder}

Substance use disorders are characterized by the inability to control using legal or illegal drugs or medication, such as marijuana, stimulants, and heroin, as well as nicotine, and alcohol. Men have a higher tendency to use illicit drugs and alcohol than women. Further differences lie in the treatment adherence, illness course, and comorbidities. For example, women generally seek help earlier and have a higher prevalence of comorbid psychiatric disorders than men [213].

\section{Alcohol Use Disorder}

Amongst the different substances in substance use disorders, most literature exists in investigating alcohol use disorder. Men and women have different reasons for binge drinking. Women drink for self-medication and soothing mood disturbances [213]. Further, women often have worse health outcomes from the abuse, including liver disease and brain damage [214,215].

Studies have reported estrogen and estrogen signaling involved in alcohol-abusing behaviors. The estrogen level is positively associated with alcohol consumption [216] in humans and in rodents [217]. Further, a recent study showed that ER $\alpha$ promotes the ethanol response of ventral tegmental area neurons, the process of which requires mGLuR1 activity. To add more, the study observed a more dramatic effect of ER $\alpha$ reduction in the ventral tegmental area (VTA) on binge-like drinking behavior than ER $\beta$. However, the effect was only observed in female mice and not male mice, providing evidence that alcohol use disorder treatments may need to take into account genders [218].

\section{Conclusions}

Extensive literature supports estrogen and estrogen-signaling disruptions across the psychiatric illnesses of schizophrenia, bipolar disorder, MDD, ASD, ADHD, GAD, PTSD, eating disorders, and substance use disorders. Estrogens and estrogen signaling play a pertinent role in the regulation of neurotransmitter systems, such as dopaminergic, serotonergic, and glutamatergic, and actively participate in cognitive functioning - most importantly, memory. Further, they provide neuroprotective and anti-inflammatory effects. Estrogen and estrogen signaling are disrupted in multiple psychiatric disorders, with varying degrees of disruptions affecting different downstream cell cascades. Future studies elucidating estrogen and estrogen-signaling disruptions and possible novel treatment strategies in major psychiatric disorders are warranted.

Author Contributions: W.J.H. contributed to performing the literature search, analyzing the data, and drafting the article. T.Y.L. contributed to planning the literature search, analyzing the data, and editing the manuscript. N.S.K. contributed to performing the literature search and drafting the article. J.S.K. contributed to planning the literature search and editing the manuscript. All authors have read and agreed to the published version of the manuscript. 
Funding: This research was supported by a grant of the Korea Health Technology R\&D Project through the Korea Health Industry Development Institute (KHIDI) funded by the Ministry of Health \& Welfare, Republic of Korea (grant number: HI19C1080), and the Brain Research Program and Basic Science Research Program through the National Research Foundation of Korea (NRF) funded by the Ministry of Science, ICT \& Future Planning (grant numbers: 2017M3C7A1029610 and 2019R1A2B5B03100844), and the Research Institute for Convergence of Biomedical Science and Technology, Pusan National University Yangsan Hospital (20-2020-009).

Conflicts of Interest: The authors declare no conflict of interest.

Abbreviatio
ADHD
Akt
ASD
BDNF
BPA
CA1
CA2
CA3
cAMP
CSTC
ER $\alpha$
ER $\beta$
ERE
ERK
ERT
fMRI
GPER
HDAC4
MAPK
NTD
PI3K
PKA
SERMs
Wnt

Attention-deficit hyperactivity disorder
Protein kinase B
Autism spectrum disorder
Brain-derived neurotrophic factor
Bisphenol A
Cornu ammonis 1
Cornu ammonis 2
Cornu ammonis 3
Cyclic adenosine monophosphate
Cortico-striato-thalamo-cortical
Estrogen receptor alpha
Estrogen receptor beta
Estrogen response elements
Extracellular signal-regulated kinase
Estrogen replacement therapy
Functional magnetic resonance imaging
G-protein coupled receptor 30
Histone deacetylase 4
Mitogen-activated protein kinase
Amino-terminal domain
Phosphatidylinositol 3-kinase
Protein kinase A
Selective estrogen receptor modulators
Wingless-int

\section{References}

1. Our World in Data. Global Mental Health: Five Key Insights Which Emerge from the Data. Available online: https:// ourworldindata.org/global-mental-health (accessed on 29 November 2020).

2. Findlay, J.K.; Liew, S.H.; Simpson, E.R.; Korach, K.S. Estrogen Signaling in the Regulation of Female Reproductive Functions. Handb. Exp. Pharmacol. 2010, 198, 29-35.

3. Colzato, L.S.; Hommel, B. Effects of estrogen on higher-order cognitive functions in unstressed human females may depend on individual variation in dopamine baseline levels. Front. Neurosci. 2014, 8, 65. [CrossRef] [PubMed]

4. Almey, A.; Milner, T.A.; Brake, W.G. Estrogen receptors in the central nervous system and their implication for dopaminedependent cognition in females. Horm. Behav. 2015, 74, 125-138. [CrossRef] [PubMed]

5. Frizell, B.; Dumas, J.A. Examining the Relationship Between Neurosteroids, Cognition, and Menopause With Neuroimaging Methods. Curr. Psychiatry Rep. 2018, 20, 96. [CrossRef]

6. Gasbarri, A.; Pompili, A.; D'Onofrio, A.; Cifariello, A.; Tavares, M.C.; Tomaz, C. Working memory for emotional facial expressions: Role of the estrogen in young women. Psychoneuroendocrinology 2008, 33, 964-972. [CrossRef]

7. Dreher, J.-C.; Schmidt, P.J.; Kohn, P.; Furman, D.; Rubinow, D.; Berman, K.F. Menstrual cycle phase modulates reward-related neural function in women. Proc. Natl. Acad. Sci. USA 2007, 104, 2465-2470. [CrossRef]

8. Jacobs, E.; D'Esposito, M. Estrogen shapes dopamine-dependent cognitive processes: Implications for women's health. J. Neurosci. Off. J. Soc. Neurosci. 2011, 31, 5286-5293. [CrossRef]

9. Saldanha, C.J. Estrogen as a Neuroprotectant in Both Sexes: Stories From the Bird Brain. Front. Neurol. 2020, 11, 497. [CrossRef]

10. Azcoitia, I.; Barreto, G.E.; Garcia-Segura, L.M. Molecular mechanisms and cellular events involved in the neuroprotective actions of estradiol. Analysis of sex differences. Front. Neuroendocrinol. 2019, 55, 100787. [CrossRef]

11. McGregor, C.; Riordan, A.; Thornton, J. Estrogens and the cognitive symptoms of schizophrenia: Possible neuroprotective mechanisms. Front. Neuroendocrinol. 2017, 47, 19-33. [CrossRef] 
12. Gogos, A.; Ney, L.J.; Seymour, N.; Van Rheenen, T.E.; Felmingham, K.L. Sex differences in schizophrenia, bipolar disorder, and post-traumatic stress disorder: Are gonadal hormones the link? Br. J. Pharmacol. 2019, 176, 4119-4135. [CrossRef] [PubMed]

13. Crider, A.; Pillai, A. Estrogen Signaling as a Therapeutic Target in Neurodevelopmental Disorders. J. Pharmacol. Exp. Ther. 2017, 360, 48-58. [CrossRef] [PubMed]

14. Cho, M.; Lee, T.Y.; Kwak, Y.B.; Yoon, Y.B.; Kim, M.; Kwon, J.S. Adjunctive use of anti-inflammatory drugs for schizophrenia: A meta-analytic investigation of randomized controlled trials. Aust. N. Z. J. Psychiatry 2019, 53, 742-759. [CrossRef] [PubMed]

15. Kulkarni, J.; Butler, S.; Riecher-Rössler, A. Estrogens and SERMS as adjunctive treatments for schizophrenia. Front. Neuroendocrinol. 2019, 53, 100743. [CrossRef]

16. Çakici, N.; van Beveren, N.J.M.; Judge-Hundal, G.; Koola, M.M.; Sommer, I.E.C. An update on the efficacy of anti-inflammatory agents for patients with schizophrenia: A meta-analysis. Psychol. Med. 2019, 49, 2307-2319. [CrossRef]

17. Dwyer, J.B.; Aftab, A.; Radhakrishnan, R.; Widge, A.; Rodriguez, C.I.; Carpenter, L.L.; Nemeroff, C.B.; McDonald, W.M.; Kalin, N.H. Hormonal Treatments for Major Depressive Disorder: State of the Art. Am. J. Psychiatry 2020, 177, 686-705. [CrossRef]

18. Jeppesen, R.; Christensen, R.H.B.; Pedersen, E.M.J.; Nordentoft, M.; Hjorthøj, C.; Köhler-Forsberg, O.; Benros, M.E. Efficacy and safety of anti-inflammatory agents in treatment of psychotic disorders-A comprehensive systematic review and meta-analysis. Brain Behav. Immun. 2020, 90, 364-380. [CrossRef]

19. Sherwin, B.B. Estrogen and Cognitive Functioning in Women: Lessons We Have Learned. Behav Neurosci. 2012, 126, 123-127. [CrossRef]

20. Liang, J.; Shang, Y. Estrogen and cancer. Annu. Rev. Physiol. 2013, 75, 225-240. [CrossRef]

21. Sayed, Y.; Taxel, P. The use of estrogen therapy in men. Curr. Opin. Pharmacol. 2003, 3, 650-654. [CrossRef]

22. Schulster, M.; Bernie, A.M.; Ramasamy, R. The role of estradiol in male reproductive function. Asian J. Androl. 2016, 18, 435-440. [PubMed]

23. Gruber, C.J.; Tschugguel, W.; Schneeberger, C.; Huber, J.C. Production and actions of estrogens. N. Engl. J. Med. 2002, 346, 340-352. [CrossRef] [PubMed]

24. Denley, M.C.S.; Gatford, N.J.F.; Sellers, K.J.; Srivastava, D.P. Estradiol and the Development of the Cerebral Cortex: An Unexpected Role? Front. Neurosci. 2018, 12, 245. [CrossRef] [PubMed]

25. Azcoitia, I.; Arevalo, M.-A.; De Nicola, A.F.; Garcia-Segura, L.M. Neuroprotective actions of estradiol revisited. Trends Endocrinol. Metab. 2011, 22, 467-473. [CrossRef] [PubMed]

26. Prossnitz, E.R.; Sklar, L.A.; Oprea, T.I.; Arterburn, J.B. GPR30: A novel therapeutic target in estrogen-related disease. Trends Pharmacol. Sci. 2008, 29, 116-123. [CrossRef] [PubMed]

27. Vrtačnik, P.; Ostanek, B.; Mencej-Bedrač, S.; Marc, J. The many faces of estrogen signaling. Biochem. Med. 2014, 24, 329-342. [CrossRef] [PubMed]

28. Liu, M.-M.; Albanese, C.; Anderson, C.M.; Hilty, K.; Webb, P.; Uht, R.M.; Price, R.H., Jr.; Pestell, R.G.; Kushner, P.J. Opposing action of estrogen receptors alpha and beta on cyclin D1 gene expression. J. Biol. Chem. 2002, 277, 24353-24360. [CrossRef]

29. Marino, M.; Galluzzo, P.; Ascenzi, P. Estrogen signaling multiple pathways to impact gene transcription. Curr. Genom. 2006, 7 , 497-508. [CrossRef]

30. Fuentes, N.; Silveyra, P. Estrogen receptor signaling mechanisms. Adv. Protein Chem. Struct. Biol. 2019, 116, 135-170.

31. Hwang, W.J.; Cho, K.I.K.; Kwak, Y.B.; Lee, J.; Kim, M.; Lee, T.Y.; Kwon, J.S. Intact thalamic microstructure in asymptomatic relatives of schizophrenia patients with high genetic loading. Schizophr. Res. 2020. [CrossRef]

32. Prossnitz, E.R.; Arterburn, J.B. International Union of Basic and Clinical Pharmacology. XCVII. G Protein-Coupled Estrogen Receptor and Its Pharmacologic Modulators. Pharmacol. Rev. 2015, 67, 505-540. [CrossRef] [PubMed]

33. Montague, D.; Weickert, C.S.; Tomaskovic-Crook, E.; Rothmond, D.A.; Kleinman, J.E.; Rubinow, D.R. Oestrogen receptor alpha localisation in the prefrontal cortex of three mammalian species. J. Neuroendocrinol. 2008, 20, 893-903. [CrossRef] [PubMed]

34. Kritzer, M.F. Regional, laminar, and cellular distribution of immunoreactivity for ER alpha and ER beta in the cerebral cortex of hormonally intact, adult male and female rats. Cereb. Cortex 2002, 12, 116-128. [CrossRef] [PubMed]

35. Shughrue, P.J.; Lane, M.V.; Merchenthaler, I. Comparative distribution of estrogen receptor-alpha and -beta mRNA in the rat central nervous system. J. Comp. Neurol. 1997, 388, 507-525. [CrossRef]

36. González, M.; Cabrera-Socorro, A.; Pérez-García, C.G.; Fraser, J.D.; López, F.J.; Alonso, R.; Meyer, G. Distribution patterns of estrogen receptor alpha and beta in the human cortex and hippocampus during development and adulthood. J. Comp. Neurol. 2007, 503, 790-802. [CrossRef]

37. Ostlund, H.; Keller, E.; Hurd, Y.L. Estrogen receptor gene expression in relation to neuropsychiatric disorders. Ann. N. Y. Acad. Sci. 2003, 1007, 54-63. [CrossRef]

38. Simerly, R.B.; Chang, C.; Muramatsu, M.; Swanson, L.W. Distribution of androgen and estrogen receptor mRNA-containing cells in the rat brain: An in situ hybridization study. J. Comp. Neurol. 1990, 294, 76-95. [CrossRef]

39. Osterlund, M.K.; Gustafsson, J.A.; Keller, E.; Hurd, Y.L. Estrogen receptor beta (ERbeta) messenger ribonucleic acid (mRNA) expression within the human forebrain: Distinct distribution pattern to ERalpha mRNA. J. Clin. Endocrinol. Metab. 2000, 85, 3840-3846.

40. Osterlund, M.K.; Keller, E.; Hurd, Y.L. The human forebrain has discrete estrogen receptor alpha messenger RNA expression: High levels in the amygdaloid complex. Neuroscience 2000, 95, 333-342. [CrossRef] 
41. Purves-Tyson, T.D.; Handelsman, D.J.; Double, K.L.; Owens, S.J.; Bustamante, S.; Weickert, C.S. Testosterone regulation of sex steroid-related mRNAs and dopamine-related mRNAs in adolescent male rat substantia nigra. BMC Neurosci. $2012,13,95$. [CrossRef]

42. Sánchez, M.G.; Bourque, M.; Morissette, M.; Di Paolo, T. Steroids-dopamine interactions in the pathophysiology and treatment of CNS disorders. CNS Neurosci Ther. 2010, 16, e43-e71. [CrossRef]

43. Yoest, K.E.; Cummings, J.A.; Becker, J.B. Oestradiol influences on dopamine release from the nucleus accumbens shell: Sex differences and the role of selective oestradiol receptor subtypes. Br. J. Pharmacol. 2019, 176, 4136-4148. [CrossRef]

44. Wang, J.-X.; Zhuang, J.-Y.; Fu, L.; Lei, Q.; Fan, M.; Zhang, W. How ovarian hormones influence the behavioral activation and inhibition system through the dopamine pathway. PLOS ONE. 2020, 15, e0237032.

45. Küppers, E.; Beyer, C. Expression of estrogen receptor-alpha and beta mRNA in the developing and adult mouse striatum. Neurosci Lett. 1999, 276, 95-98. [CrossRef]

46. Mitra, S.W.; Hoskin, E.; Yudkovitz, J.; Pear, L.; Wilkinson, H.A.; Hayashi, S.; Pfaff, D.W.; Ogawa, S.; Rohrer, S.P.; Schaeffer, J.M.; et al. Immunolocalization of estrogen receptor beta in the mouse brain: Comparison with estrogen receptor alpha. Endocrinology 2003, 144, 2055-2067. [CrossRef] [PubMed]

47. Kruijver, F.P.M.; Balesar, R.; Espila, A.M.; Unmehopa, U.A.; Swaab, D.F. Estrogen-receptor-beta distribution in the human hypothalamus: Similarities and differences with ER alpha distribution. J. Comp. Neurol. 2003, 466, 251-277. [CrossRef] [PubMed]

48. Bacqué-Cazenave, J.; Bharatiya, R.; Barrière, G.; Delbecque, J.-P.; Bouguiyoud, N.; Di Giovanni, G.; Cattaert, D.; De Deurwaerdère, P. Serotonin in Animal Cognition and Behavior. Int. J. Mol. Sci. 2020, 21, 1649. [CrossRef] [PubMed]

49. Buhot, M.C. Serotonin receptors in cognitive behaviors. Curr. Opin. Neurobiol. 1997, 7, 243-254. [CrossRef]

50. Krolick, K.N.; Zhu, Q.; Shi, H. Effects of Estrogens on Central Nervous System Neurotransmission: Implications for Sex Differences in Mental Disorders. Prog. Mol. Biol. Transl. Sci. 2018, 160, 105-171. [PubMed]

51. Pecins-Thompson, M.; Brown, N.A.; Kohama, S.G.; Bethea, C.L. Ovarian steroid regulation of tryptophan hydroxylase mRNA expression in rhesus macaques. J. Neurosci. Off. J. Soc. Neurosci. 1996, 16, 7021-7029. [CrossRef]

52. Maharjan, S.; Serova, L.I.; Sabban, E.L. Membrane-initiated estradiol signaling increases tyrosine hydroxylase promoter activity with ER alpha in PC12 cells. J. Neurochem. 2010, 112, 42-55. [CrossRef]

53. Becker, J.B. Estrogen rapidly potentiates amphetamine-induced striatal dopamine release and rotational behavior during microdialysis. Neurosci. Lett. 1990, 118, 169-171. [CrossRef]

54. Becker, J.B.; Ramirez, V.D. Experimental studies on the development of sex differences in the release of dopamine from striatal tissue fragments in vitro. Neuroendocrinology 1981, 32, 168-173. [CrossRef]

55. Becker, J.; Ramirez, V.D. Dynamics of endogenous catecholamine release from brain fragments of male and female rats. Neuroendocrinology 1980, 31, 18-25. [CrossRef]

56. Hernández, M.L.; Fernández-Ruiz, J.J.; de Miguel, R.; Ramos, J.A. Time-dependent effects of ovarian steroids on tyrosine hydroxylase activity in the limbic forebrain of female rats. J. Neural Transm. Gen. Sect. 1991, 83, 77-84. [CrossRef]

57. Wallin-Miller, K.G.; Chesley, J.; Castrillon, J.; Wood, R.I. Sex differences and hormonal modulation of ethanol-enhanced risk taking in rats. Drug Alcohol. Depend. 2017, 174, 137-144. [CrossRef]

58. Hruska, R.E.; Nowak, M.W. Estrogen treatment increases the density of D1 dopamine receptors in the rat striatum. Brain Res. 1988, 442, 349-350. [CrossRef]

59. Czoty, P.W.; Riddick, N.V.; Gage, H.D.; Sandridge, M.; Nader, S.H.; Garg, S.; Bounds, M.; Garg, P.K.; Nader, M.A. Effect of menstrual cycle phase on dopamine D2 receptor availability in female cynomolgus monkeys. Neuropsychopharmacol. Off. Publ. Am. Coll. Neuropsychopharmacol. 2009, 34, 548-554. [CrossRef]

60. Bazzett, T.J.; Becker, J.B. Sex differences in the rapid and acute effects of estrogen on striatal D2 dopamine receptor binding. Brain Res. 1994, 637, 163-172. [CrossRef]

61. Disshon, K.A.; Boja, J.W.; Dluzen, D.E. Inhibition of striatal dopamine transporter activity by 17beta-estradiol. Eur. J. Pharmacol. 1998, 345, 207-211. [CrossRef]

62. Rehavi, M.; Goldin, M.; Roz, N.; Weizman, A. Regulation of rat brain vesicular monoamine transporter by chronic treatment with ovarian hormones. Brain Res. Mol. Brain Res. 1998, 57, 31-37. [CrossRef]

63. Chavez, C.; Hollaus, M.; Scarr, E.; Pavey, G.; Gogos, A.; van den Buuse, M. The effect of estrogen on dopamine and serotonin receptor and transporter levels in the brain: An autoradiography study. Brain Res. 2010, 1321, 51-59. [CrossRef]

64. Bethea, C.L.; Mirkes, S.J.; Shively, C.A.; Adams, M.R. Steroid regulation of tryptophan hydroxylase protein in the dorsal raphe of macaques. Biol Psychiatry 2000, 47, 562-576. [CrossRef]

65. Sumner, B.E.; Fink, G. Testosterone as well as estrogen increases serotonin2A receptor mRNA and binding site densities in the male rat brain. Brain Res. Mol. Brain Res. 1998, 59, 205-214. [CrossRef]

66. Sumner, B.E.; Fink, G. Effects of acute estradiol on 5-hydroxytryptamine and dopamine receptor subtype mRNA expression in female rat brain. Mol. Cell. Neurosci. 1993, 4, 83-92. [CrossRef]

67. Biegon, A.; Reches, A.; Snyder, L.; McEwen, B.S. Serotonergic and noradrenergic receptors in the rat brain: Modulation by chronic exposure to ovarian hormones. Life Sci. 1983, 32, 2015-2021. [CrossRef]

68. Cyr, M.; Bossé, R.; Di Paolo, T. Gonadal hormones modulate 5-hydroxytryptamine2A receptors: Emphasis on the rat frontal cortex. Neuroscience 1998, 83, 829-836. [CrossRef] 
69. Gundlah, C.; Pecins-Thompson, M.; Schutzer, W.E.; Bethea, C.L. Ovarian steroid effects on serotonin 1A, 2A and 2C receptor mRNA in macaque hypothalamus. Brain Res. Mol. Brain Res. 1999, 63, 325-339. [CrossRef]

70. Rivera, H.M.; Santollo, J.; Nikonova, L.V.; Eckel, L.A. Estradiol increases the anorexia associated with increased 5-HT(2C) receptor activation in ovariectomized rats. Physiol. Behav. 2012, 105, 188-194. [CrossRef]

71. Singh, A.; Lucki, I. Antidepressant-like activity of compounds with varying efficacy at 5-HT1A receptors. Neuropharmacology 1993, 32, 331-340. [CrossRef]

72. Hoffman, B.J.; Hansson, S.R.; Mezey, E.; Palkovits, M. Localization and dynamic regulation of biogenic amine transporters in the mammalian central nervous system. Front. Neuroendocrinol. 1998, 19, 187-231. [CrossRef]

73. Holschneider, D.P.; Kumazawa, T.; Chen, K.; Shih, J.C. Tissue-specific effects of estrogen on monoamine oxidase A and B in the rat. Life Sci. 1998, 63, 155-160. [CrossRef]

74. Ortega-Corona, B.G.; Valencia-Sánchez, A.; Kubli-Garfias, C.; Anton-Tay, F.; Salazar, L.A.; Villarreal, J.E.; Ponce-Monter, H. Hypothalamic monoamine oxidase activity in ovariectomized rats after sexual behavior restoration. Arch. Med. Res. 1994, 25, 337-340.

75. Gazzaley, A.H.; Weiland, N.G.; McEwen, B.S.; Morrison, J.H. Differential regulation of NMDAR1 mRNA and protein by estradiol in the rat hippocampus. J. Neurosci. Off. J. Soc. Neurosci. 1996, 16, 6830-6838. [CrossRef]

76. Adams, M.M.; Fink, S.E.; Janssen, W.G.M.; Shah, R.A.; Morrison, J.H. Estrogen modulates synaptic N-methyl-D-aspartate receptor subunit distribution in the aged hippocampus. J. Comp. Neurol. 2004, 474, 419-426. [CrossRef]

77. Woolley, C.S.; Weiland, N.G.; McEwen, B.S.; Schwartzkroin, P.A. Estradiol increases the sensitivity of hippocampal CA1 pyramidal cells to NMDA receptor-mediated synaptic input: Correlation with dendritic spine density. J. Neurosci. Off. J. Soc. Neurosci. 1997, 17, 1848-1859. [CrossRef]

78. Kurata, K.; Takebayashi, M.; Morinobu, S.; Yamawaki, S. beta-estradiol, dehydroepiandrosterone, and dehydroepiandrosterone sulfate protect against N-methyl-D-aspartate-induced neurotoxicity in rat hippocampal neurons by different mechanisms. J. Pharmacol. Exp. Ther. 2004, 311, 237-245. [CrossRef]

79. Kajta, M.; Lasoń, W. Oestrogen effects on kainate-induced toxicity in primary cultures of rat cortical neurons. Acta Neurobiol. Exp. 2000, 60, 365-369.

80. Fischer, B.; Gleason, C.; Asthana, S. Effects of hormone therapy on cognition and mood. Fertil. Steril. 2014, 101, 898-904. [CrossRef]

81. Verghese, J.; Kuslansky, G.; Katz, M.J.; Sliwinski, M.; Crystal, H.A.; Buschke, H.; Lipton, R.B. Cognitive performance in surgically menopausal women on estrogen. Neurology 2000, 55, 872-874. [CrossRef]

82. Rissman, E.F.; Heck, A.L.; Leonard, J.E.; Shupnik, M.A.; Gustafsson, J.-A. Disruption of estrogen receptor beta gene impairs spatial learning in female mice. Proc. Natl. Acad. Sci. USA 2002, 99, 3996-4001. [CrossRef]

83. Rissman, E.F.; Wersinger, S.R.; Fugger, H.N.; Foster, T.C. Sex with knockout models: Behavioral studies of estrogen receptor alpha. Brain Res. 1999, 835, 80-90. [CrossRef]

84. Hara, Y.; Waters, E.M.; McEwen, B.S.; Morrison, J.H. Estrogen Effects on Cognitive and Synaptic Health Over the Lifecourse. Physiol Rev. 2015, 95, 785-807. [CrossRef]

85. Khan, M.M.; Wakade, C.; de Sevilla, L.; Brann, D.W. Selective estrogen receptor modulators (SERMs) enhance neurogenesis and spine density following focal cerebral ischemia. J. Steroid Biochem. Mol. Biol. 2015, 146, 38-47. [CrossRef]

86. Lu, Y.; Sareddy, G.R.; Wang, J.; Wang, R.; Li, Y.; Dong, Y.; Zhang, Q.; Liu, J.; O'Connor, J.C.; Xu, J.; et al. Neuron-Derived Estrogen Regulates Synaptic Plasticity and Memory. J. Neurosci. 2019, 39, 2792-2809. [CrossRef]

87. Hampson, E. Estrogens, Aging, and Working Memory. Curr. Psychiatry Rep. 2018, 20, 109. [CrossRef]

88. Bastos, C.P.; Pereira, L.M.; Ferreira-Vieira, T.H.; Drumond, L.E.; Massensini, A.R.; Moraes, M.F.D.; Pereira, G.S. Object recognition memory deficit and depressive-like behavior caused by chronic ovariectomy can be transitorialy recovered by the acute activation of hippocampal estrogen receptors. Psychoneuroendocrinology 2015, 57, 14-25. [CrossRef]

89. Duff, S.J.; Hampson, E. A Beneficial Effect of Estrogen on Working Memory in Postmenopausal Women Taking Hormone Replacement Therapy. Horm. Behav. 2000, 38, 262-276. [CrossRef]

90. Hussain, D.; Hanafi, S.; Konishi, K.; Brake, W.G.; Bohbot, V.D. Modulation of spatial and response strategies by phase of the menstrual cycle in women tested in a virtual navigation task. Psychoneuroendocrinology 2016, 70, 108-117. [CrossRef]

91. Wallace, M.; Luine, V.; Arellanos, A.; Frankfurt, M. Ovariectomized rats show decreased recognition memory and spine density in the hippocampus and prefrontal cortex. Brain Res. 2006, 1126, 176-182. [CrossRef]

92. Tuscher, J.J.; Luine, V.; Frankfurt, M.; Frick, K.M. Estradiol-Mediated Spine Changes in the Dorsal Hippocampus and Medial Prefrontal Cortex of Ovariectomized Female Mice Depend on ERK and mTOR Activation in the Dorsal Hippocampus. J. Neurosci. Off. J. Soc. Neurosci. 2016, 36, 1483-1489. [CrossRef]

93. Engler-Chiurazzi, E.B.; Singh, M.; Simpkins, J.W. Reprint of: From the 90's to now: A brief historical perspective on more than two decades of estrogen neuroprotection. Brain Res. 2016, 1645, 79-82. [CrossRef]

94. Hwang, W.J.; Lee, T.Y.; Shin, W.-G.; Kim, M.; Kim, J.; Lee, J.; Kwon, J.S. Global and Specific Profiles of Executive Functioning in Prodromal and Early Psychosis. Front. Psychiatry 2019, 10, 356. [CrossRef]

95. Bloemen, A.J.P.; Oldehinkel, A.J.; Laceulle, O.M.; Ormel, J.; Rommelse, N.N.J.; Hartman, C.A. The association between executive functioning and psychopathology: General or specific? Psychol. Med. 2018, 48, 1787-1794. [CrossRef] 
96. Sinkeviciute, I.; Begemann, M.; Prikken, M.; Oranje, B.; Johnsen, E.; Lei, W.U.; Hugdahl, K.; Kroken, R.A.; Rau, C.; Jacobs, J.D.; et al. Efficacy of different types of cognitive enhancers for patients with schizophrenia: A meta-analysis. NPJ Schizophr. 2018, 4, 1-14. [CrossRef]

97. Goff, D.C.; Hill, M.; Barch, D. The treatment of cognitive impairment in schizophrenia. Pharmacol. Biochem. Behav. 2011, 99, 245-253. [CrossRef]

98. Keefe, R.S.E.; Meltzer, H.A.; Dgetluck, N.; Gawryl, M.; Koenig, G.; Moebius, H.J.; Lombardo, I.; Hilt, D.C. Randomized, DoubleBlind, Placebo-Controlled Study of Encenicline, an $\alpha 7$ Nicotinic Acetylcholine Receptor Agonist, as a Treatment for Cognitive Impairment in Schizophrenia. Neuropsychopharmacol. Off. Publ. Am. Coll. Neuropsychopharmacol. 2015, 40, 3053-3060. [CrossRef]

99. Pietrzak, R.H.; Olver, J.; Norman, T.; Piskulic, D.; Maruff, P.; Snyder, P.J. A comparison of the CogState Schizophrenia Battery and the Measurement and Treatment Research to Improve Cognition in Schizophrenia (MATRICS) Battery in assessing cognitive impairment in chronic schizophrenia. J. Clin. Exp. Neuropsychol. 2009, 31, 848-859. [CrossRef]

100. Nuechterlein, K.H.; Green, M.F.; Kern, R.S.; Baade, L.E.; Barch, D.M.; Cohen, J.D.; Essock, S.; Fenton, W.S.; Frese, F.J., 3rd; Gold, J.M.; et al. The MATRICS Consensus Cognitive Battery, part 1: Test selection, reliability, and validity. Am. J. Psychiatry 2008, 165, 203-213. [CrossRef]

101. Michalopoulou, P.G.; Lewis, S.W.; Drake, R.J.; Reichenberg, A.; Emsley, R.; Kalpakidou, A.K.; Lees, J.; Bobin, T.; Gilleen, J.K.; Pandina, G.; et al. Modafinil combined with cognitive training: Pharmacological augmentation of cognitive training in schizophrenia. Eur. Neuropsychopharmacol. J. Eur. Coll. Neuropsychopharmacol. 2015, 25, 1178-1189. [CrossRef]

102. Harper-Harrison, G.; Shanahan, M.M. Hormone Replacement Therapy. In StatPearls; StatPearls Publishing: Treasure Island, FL, USA, 2020; Available online: http:/ / www.ncbi.nlm.nih.gov/books/NBK493191/ (accessed on 29 November 2020).

103. Abdelhamid, R.; Luo, J.; Vandevrede, L.; Kundu, I.; Michalsen, B.; Litosh, V.A.; Schiefer, I.T.; Gherezghiher, T.; Yao, P.; Qin, Z.; et al. Benzothiophene Selective Estrogen Receptor Modulators Provide Neuroprotection by a novel GPR30-dependent Mechanism. ACS Chem. Neurosci. 2011, 2, 256-268. [CrossRef] [PubMed]

104. Bourque, M.; Morissette, M.; Di Paolo, T. Raloxifene activates G protein-coupled estrogen receptor 1/Akt signaling to protect dopamine neurons in 1-methyl-4-phenyl-1,2,3,6-tetrahydropyridine mice. Neurobiol. Aging 2014, 35, 2347-2356. [CrossRef] [PubMed]

105. Salgado, I.K.; Torrado, A.I.; Santiago, J.M.; Miranda, J.D. Tamoxifen and Src kinase inhibitors as neuroprotective/neuroregenerative drugs after spinal cord injury. Neural Regen. Res. 2015, 10, 385-390. [PubMed]

106. Kuiper, G.G.; Lemmen, J.G.; Carlsson, B.; Corton, J.C.; Safe, S.H.; van der Saag, P.T.; van der Burg, B.; Gustafsson, J.A. Interaction of estrogenic chemicals and phytoestrogens with estrogen receptor beta. Endocrinology 1998, 139, 4252-4263. [CrossRef] [PubMed]

107. Yazğan, B.; Yazğan, Y.; Övey, İ.S.; Nazıroğlu, M. Raloxifene and Tamoxifen Reduce PARP Activity, Cytokine and Oxidative Stress Levels in the Brain and Blood of Ovariectomized Rats. J. Mol. Neurosci. 2016, 60, 214-222. [CrossRef]

108. Ishihara, Y.; Itoh, K.; Ishida, A.; Yamazaki, T. Selective estrogen-receptor modulators suppress microglial activation and neuronal cell death via an estrogen receptor-dependent pathway. J. Steroid Biochem. Mol. Biol. 2015, 145, 85-93. [CrossRef]

109. DonCarlos, L.L.; Azcoitia, I.; Garcia-Segura, L.M. Neuroprotective actions of selective estrogen receptor modulators. Psychoneuroendocrinology 2009, 34 (Suppl. S1), S113-S122. [CrossRef]

110. Arevalo, M.A.; Santos-Galindo, M.; Lagunas, N.; Azcoitia, I.; Garcia-Segura, L.M. Selective estrogen receptor modulators as brain therapeutic agents. J. Mol. Endocrinol. 2011, 46, R1-R9. [CrossRef]

111. Brann, D.W.; Dhandapani, K.; Wakade, C.; Mahesh, V.B.; Khan, M.M. Neurotrophic and neuroprotective actions of estrogen: Basic mechanisms and clinical implications. Steroids 2007, 72, 381-405. [CrossRef]

112. Lu, Y.; Sareddy, G.R.; Wang, J.; Zhang, Q.; Tang, F.-L.; Pratap, U.P.; Tekmal, R.R.; Vadlamudi, R.K.; Brann, D.W. Neuron-Derived Estrogen Is Critical for Astrocyte Activation and Neuroprotection of the Ischemic Brain. J. Neurosci. 2020, 40, 7355-7374. [CrossRef]

113. Babayan, A.H.; Kramár, E.A. Rapid Effects of Oestrogen on Synaptic Plasticity: Interactions with Actin and its Signaling Proteins. J. Neuroendocrinol. 2013, 25, 1163-1172. [CrossRef] [PubMed]

114. Lewis-Wambi, J.S.; Jordan, V.C. Estrogen regulation of apoptosis: How can one hormone stimulate and inhibit? Breast Cancer Res. 2009, 11, 206. [CrossRef] [PubMed]

115. Goodman, Y.; Bruce, A.J.; Cheng, B.; Mattson, M.P. Estrogens attenuate and corticosterone exacerbates excitotoxicity, oxidative injury, and amyloid beta-peptide toxicity in hippocampal neurons. J. Neurochem. 1996, 66, 1836-1844. [CrossRef] [PubMed]

116. Behl, C.; Widmann, M.; Trapp, T.; Holsboer, F. 17-beta estradiol protects neurons from oxidative stress-induced cell death in vitro. Biochem. Biophys. Res. Commun. 1995, 216, 473-482. [CrossRef]

117. Rettberg, J.R.; Yao, J.; Brinton, R.D. Estrogen: A master regulator of bioenergetic systems in the brain and body. Front. Neuroendocrinol. 2014, 35, 8-30. [CrossRef]

118. Villa, A.; Vegeto, E.; Poletti, A.; Maggi, A. Estrogens, Neuroinflammation, and Neurodegeneration. Endocr. Rev. 2016, 37, $372-402$. [CrossRef]

119. Zhang, Z.; Qin, P.; Deng, Y.; Ma, Z.; Guo, H.; Guo, H.; Hou, Y.; Wang, S.; Zou, W.; Sun, Y.; et al. The novel estrogenic receptor GPR30 alleviates ischemic injury by inhibiting TLR4-mediated microglial inflammation. J. Neuroinflamm. 2018, 15, 206. [CrossRef]

120. Hill, R.A.; van den Buuse, M. Sex-dependent and region-specific changes in TrkB signaling in BDNF heterozygous mice. Brain Res. 2011, 1384, 51-60. [CrossRef]

121. Brown, C.M.; Mulcahey, T.A.; Filipek, N.C.; Wise, P.M. Production of proinflammatory cytokines and chemokines during neuroinflammation: Novel roles for estrogen receptors alpha and beta. Endocrinology 2010, 151, 4916-4925. [CrossRef] 
122. Scott, E.; Zhang, Q.; Wang, R.; Vadlamudi, R.; Brann, D. Estrogen neuroprotection and the critical period hypothesis. Front. Neuroendocrinol. 2012, 33, 85-104. [CrossRef]

123. Jablensky, A.; McGrath, J.; Herrman, H.; Castle, D.; Gureje, O.; Evans, M.; Carr, V.; Morgan, V.; Korten, A.; Harvey, C. Psychotic disorders in urban areas: An overview of the Study on Low Prevalence Disorders. Aust. N. Z. J. Psychiatry 2000, 34, 221-236. [CrossRef] [PubMed]

124. Huber, T.J.; Rollnik, J.; Wilhelms, J.; von zur Mühlen, A.; Emrich, H.M.; Schneider, U. Estradiol levels in psychotic disorders. Psychoneuroendocrinology 2001, 26, 27-35. [CrossRef]

125. Biegon, A.; McEwen, B.S. Modulation by estradiol of serotonin receptors in brain. J. Neurosci. 1982, 2, 199-205. [CrossRef] [PubMed]

126. Goldstein, J.M.; Link, B.G. Gender and the expression of schizophrenia. J. Psychiatr. Res. 1988, 22, 141-155. [CrossRef]

127. Riecher-Rössler, A. Oestrogens, prolactin, hypothalamic-pituitary-gonadal axis, and schizophrenic psychoses. Lancet Psychiatry 2017, 4, 63-72. [CrossRef]

128. Mahé, V.; Dumaine, A. Oestrogen withdrawal associated psychoses. Acta Psychiatr. Scand. 2001, 104, 323-331. [CrossRef]

129. Riecher-Rössler, A.; Häfner, H.; Stumbaum, M.; Maurer, K.; Schmidt, R. Can estradiol modulate schizophrenic symptomatology? Schizophr. Bull. 1994, 20, 203-214. [CrossRef]

130. Gurvich, C.; Gavrilidis, E.; Worsley, R.; Hudaib, A.; Thomas, N.; Kulkarni, J. Menstrual cycle irregularity and menopause status influence cognition in women with schizophrenia. Psychoneuroendocrinology 2018, 96, 173-178. [CrossRef]

131. Chang, S.S.; Renshaw, D.C. Psychosis and pregnancy. Compr. Ther. 1986, 12, 36-41.

132. Wei, S.-M.; Berman, K.F. Ovarian hormones, genes, and the brain: The case of estradiol and the brain-derived neurotrophic factor (BDNF) gene. Neuropsychopharmacology 2019, 44, 223-224. [CrossRef]

133. Damme, K.S.F.; Ristanovic, I.; Vargas, T.; Mittal, V.A. Timing of menarche and abnormal hippocampal connectivity in youth at clinical-high risk for psychosis. Psychoneuroendocrinology 2020, 117, 104672. [CrossRef] [PubMed]

134. Kulkarni, J.; Gavrilidis, E.; Worsley, R.; Hayes, E. Role of estrogen treatment in the management of schizophrenia. CNS Drugs 2012, 26, 549-557. [CrossRef] [PubMed]

135. Hoff, A.L.; Kremen, W.S.; Wieneke, M.H.; Lauriello, J.; Blankfeld, H.M.; Faustman, W.O.; Csernansky, J.G.; Nordahl, T.E. Association of Estrogen Levels With Neuropsychological Performance in Women With Schizophrenia. Am. J. Psychiatry 2001, 158, 1134-1139. [CrossRef] [PubMed]

136. Mendrek, A.; Lakis, N.; Jiménez, J. Associations of sex steroid hormones with cerebral activations during mental rotation in men and women with schizophrenia. Psychoneuroendocrinology 2011, 36, 1422-1426. [CrossRef]

137. Célia Moreira Borella, V.; Seeman, M.V.; Carneiro Cordeiro, R.; Vieira dos Santos, J.; Romário Matos de Souza, M.; Nunes de Sousa Fernandes, E.; Santos Monte, A.; Maria Mendes Vasconcelos, S.; Quinn, J.P.; de Lucena, D.F.; et al. Gender and estrous cycle influences on behavioral and neurochemical alterations in adult rats neonatally administered ketamine. Dev. Neurobiol. 2016, 76, 519-532. [CrossRef]

138. Gogos, A.; Kwek, P.; van den Buuse, M. The role of estrogen and testosterone in female rats in behavioral models of relevance to schizophrenia. Psychopharmacology 2012, 219, 213-224. [CrossRef]

139. Gogos, A.; van den Buuse, M. Comparing the effects of $17 \beta$-oestradiol and the selective oestrogen receptor modulators, raloxifene and tamoxifen, on prepulse inhibition in female rats. Schizophr. Res. 2015, 168, 634-639. [CrossRef]

140. Sbisa, A.; Kusljic, S.; Zethoven, D.; van den Buuse, M.; Gogos, A. The effect of $17 \beta$-estradiol on maternal immune activationinduced changes in prepulse inhibition and dopamine receptor and transporter binding in female rats. Schizophr. Res. 2020, 223, 249-257. [CrossRef]

141. Riecher-Rössler, A.; Kulkarni, J. Estrogens and Gonadal Function in Schizophrenia and Related Psychoses. In Biological Basis of Sex Differences in Psychopharmacology; Current Topics in Behavioral Neurosciences; Neill, J.C., Kulkarni, J., Eds.; Springer: Berlin/Heidelberg, Germany, 2011; pp. 155-171. [CrossRef]

142. Da Silva, T.L.; Ravindran, A.V. Contribution of sex hormones to gender differences in schizophrenia: A review. Asian J. Psychiatry 2015, 18, 2-14. [CrossRef]

143. Perlman, W.R.; Tomaskovic-Crook, E.; Montague, D.M.; Webster, M.J.; Rubinow, D.R.; Kleinman, J.E.; Weickert, C.S. Alteration in estrogen receptor alpha mRNA levels in frontal cortex and hippocampus of patients with major mental illness. Biol. Psychiatry 2005, 58, 812-824. [CrossRef]

144. Weickert, C.S.; Miranda-Angulo, A.L.; Wong, J.; Perlman, W.R.; Ward, S.E.; Radhakrishna, V.; Straub, R.E.; Weinberger, D.R.; Kleinman, J.E. Variants in the estrogen receptor alpha gene and its mRNA contribute to risk for schizophrenia. Hum. Mol. Genet. 2008, 17, 2293-2309. [CrossRef] [PubMed]

145. Kinon, B.J.; Gilmore, J.A.; Liu, H.; Halbreich, U.M. Prevalence of hyperprolactinemia in schizophrenic patients treated with conventional antipsychotic medications or risperidone. Psychoneuroendocrinology 2003, 28 (Suppl. S2), 55-68. [CrossRef]

146. Canuso, C.M.; Goldstein, J.M.; Wojcik, J.; Dawson, R.; Brandman, D.; Klibanski, A.; Schildkraut, J.J.; Green, A.I. Antipsychotic medication, prolactin elevation, and ovarian function in women with schizophrenia and schizoaffective disorder. Psychiatry Res. 2002, 111, 11-20. [CrossRef]

147. Aston, J.; Rechsteiner, E.; Bull, N.; Borgwardt, S.; Gschwandtner, U.; Riecher-Rössler, A. Hyperprolactinaemia in early psychosisnot only due to antipsychotics. Prog. Neuropsychopharmacol. Biol. Psychiatry 2010, 34, 1342-1344. [CrossRef] [PubMed] 
148. Ittig, S.; Studerus, E.; Heitz, U.; Menghini-Müller, S.; Beck, K.; Egloff, L.; Leanza, L.; Andreou, C.; Riecher-Rössler, A. Sex differences in prolactin levels in emerging psychosis: Indication for enhanced stress reactivity in women. Schizophr. Res. 2017, 189, 111-116. [CrossRef] [PubMed]

149. Petrikis, P.; Tigas, S.; Tzallas, A.T.; Archimandriti, D.T.; Skapinakis, P.; Mavreas, V. Prolactin levels in drug-naïve patients with schizophrenia and other psychotic disorders. Int. J. Psychiatry Clin. Pract. 2016, 20, 165-169. [CrossRef] [PubMed]

150. Riecher-Rössler, A.; Rybakowski, J.K.; Pflueger, M.O.; Beyrau, R.; Kahn, R.S.; Malik, P.; Fleischhacker, W.W.; EUFEST Study Group. Hyperprolactinemia in antipsychotic-naive patients with first-episode psychosis. Psychol. Med. 2013, 43, $2571-2582$.

151. Du, X.; Hill, R.A. Hypothalamic-pituitary-gonadal axis dysfunction: An innate pathophysiology of schizophrenia? Gen. Comp. Endocrinol. 2019, 275, 38-43. [CrossRef]

152. Bergemann, N.; Parzer, P.; Jaggy, S.; Auler, B.; Mundt, C.; Maier-Braunleder, S. Estrogen and comprehension of metaphoric speech in women suffering from schizophrenia: Results of a double-blind, placebo-controlled trial. Schizophr. Bull. 2008, 34, 1172-1181. [CrossRef]

153. Kulkarni, J.; Gavrilidis, E.; Wang, W.; Worsley, R.; Fitzgerald, P.B.; Gurvich, C.; Van Rheenen, T.; Berk, M.; Burger, H. Estradiol for treatment-resistant schizophrenia: A large-scale randomized-controlled trial in women of child-bearing age. Mol. Psychiatry 2015, 20, 695-702. [CrossRef]

154. Khodaie-Ardakani, M.-R.; Khosravi, M.; Zarinfard, R.; Nejati, S.; Mohsenian, A.; Tabrizi, M.; Akhondzadeh, S. A PlaceboControlled Study of Raloxifene Added to Risperidone in Men with Chronic Schizophrenia. Acta Med. Iran. 2015, 53, 337-345. [PubMed]

155. Kulkarni, J.; Gavrilidis, E.; Gwini, S.M.; Worsley, R.; Grigg, J.; Warren, A.; Gurvich, C.; Gilbert, H.; Berk, M.; Davis, S.R. Effect of Adjunctive Raloxifene Therapy on Severity of Refractory Schizophrenia in Women: A Randomized Clinical Trial. JAMA Psychiatry 2016, 73, 947-954. [CrossRef] [PubMed]

156. Weickert, T.W.; Weinberg, D.; Lenroot, R.; Catts, S.V.; Wells, R.; Vercammen, A.; O’Donnell, M.; Galletly, C.; Liu, D.; Balzan, R.; et al. Adjunctive raloxifene treatment improves attention and memory in men and women with schizophrenia. Mol. Psychiatry 2015, 20, 685-694. [CrossRef] [PubMed]

157. Huerta-Ramos, E.; Labad, J.; Cobo, J.; Núñez, C.; Creus, M.; García-Parés, G.; Cuadras, D.; Franco, J.; Miquel, E.; Reyes, J.C.; et al. Effects of raloxifene on cognition in postmenopausal women with schizophrenia: A 24-week double-blind, randomized, parallel, placebo-controlled trial. Eur. Arch. Psychiatry Clin. Neurosci. 2020, 270, 729-737. [CrossRef]

158. Shivakumar, V.; Venkatasubramanian, G. Successful use of adjuvant raloxifene treatment in clozapine-resistant schizophrenia. Indian J. Psychiatry 2012, 54, 394. [CrossRef]

159. Orhan, F.Ö.; Kurutaş, E.B.; Doğaner, A.; Türker, E.; Özcü, S.Ş.T.; Güngör, M.; Çakmak, S. Serum levels of GPER-1 in euthymic bipolar patients. Neuropsychiatr. Dis Treat. 2018, 14, 855-862. [CrossRef]

160. Middle, F.; Jones, I.; Robertson, E.; Morey, J.; Lendon, C.; Craddock, N. Variation in the coding sequence and flanking splice junctions of the estrogen receptor alpha (ERalpha) gene does not play an important role in genetic susceptibility to bipolar disorder or bipolar affective puerperal psychosis. Am. J. Med. Genet. Part B Neuropsychiatr. Genet. Off. Publ. Int. Soc. Psychiatr. Genet. 2003, 118B, 72-75. [CrossRef]

161. Kealey, C.; Reynolds, A.; Mynett-Johnson, L.; Claffey, E.; McKeon, P. No evidence to support an association between the oestrogen receptor beta gene and bipolar disorder. Psychiatr. Genet. 2001, 11, 223-226. [CrossRef]

162. Dias, R.S.; Lafer, B.; Russo, C.; Del Debbio, A.; Nierenberg, A.A.; Sachs, G.S.; Joffe, H. Longitudinal follow-up of bipolar disorder in women with premenstrual exacerbation: Findings from STEP-BD. Am. J. Psychiatry 2011, 168, 386-394. [CrossRef]

163. Perich, T.A.; Roberts, G.; Frankland, A.; Sinbandhit, C.; Meade, T.; Austin, M.-P.; Mitchell, P.B. Clinical characteristics of women with reproductive cycle-associated bipolar disorder symptoms. Aust. N. Z. J. Psychiatry 2017, 51, 161-167. [CrossRef]

164. Fallah, E.; Arman, S.; Najafi, M.; Shayegh, B. Effect of Tamoxifen and Lithium on Treatment of Acute Mania Symptoms in Children and Adolescents. Iran. J. Child Neurol. 2016, 10, 16-25. [PubMed]

165. Palacios, J.; Yildiz, A.; Young, A.H.; Taylor, M.J. Tamoxifen for bipolar disorder: Systematic review and meta-analysis. J. Psychopharmacol. Oxf. Engl. 2019, 33, 177-184. [CrossRef] [PubMed]

166. Valvassori, S.S.; Dal-Pont, G.C.; Resende, W.R.; Varela, R.B.; Peterle, B.R.; Gava, F.F.; Mina, F.G.; Cararo, J.H.; Carvalho, A.F.; Quevedo, J. Lithium and Tamoxifen Modulate Behavior and Protein Kinase C Activity in the Animal Model of Mania Induced by Ouabain. Int. J. Neuropsychopharmacol. 2017, 20, 877-885. [CrossRef] [PubMed]

167. Bäckström, T.; Sanders, D.; Leask, R.; Davidson, D.; Warner, P.; Bancroft, J. Mood, sexuality, hormones, and the menstrual cycle. II. Hormone levels and their relationship to the premenstrual syndrome. Psychosom. Med. 1983, 45, 503-507. [CrossRef] [PubMed]

168. Findikli, E.; Kurutas, E.B.; Camkurt, M.A.; Karaaslan, M.F.; Izci, F.; Fındıklı, H.A.; Kardaş, S.; Dag, B.; Altun, H. Increased Serum G Protein-coupled Estrogen Receptor 1 Levels and Its Diagnostic Value in Drug Naïve Patients with Major Depressive Disorder. Clin. Psychopharmacol. Neurosci. Off. Sci. J. Korean Coll. Neuropsychopharmacol. 2017, 15, 337-342. [CrossRef] [PubMed]

169. Skovlund, C.W.; Mørch, L.S.; Kessing, L.V.; Lange, T.; Lidegaard, Ø. Association of Hormonal Contraception with Suicide Attempts and Suicides. Am. J. Psychiatry 2018, 175, 336-342. [CrossRef] [PubMed]

170. Skovlund, C.W.; Mørch, L.S.; Kessing, L.V.; Lidegaard, Ø. Association of Hormonal Contraception with Depression. JAMA Psychiatry 2016, 73, 1154-1162. [CrossRef]

171. Frye, C.A.; Walf, A.A. Changes in progesterone metabolites in the hippocampus can modulate open field and forced swim test behavior of proestrous rats. Horm. Behav. 2002, 41, 306-315. [CrossRef] 
172. Rachman, I.M.; Unnerstall, J.R.; Pfaff, D.W.; Cohen, R.S. Estrogen alters behavior and forebrain c-fos expression in ovariectomized rats subjected to the forced swim test. Proc. Natl. Acad. Sci. USA 1998, 95, 13941-13946. [CrossRef]

173. Hodis, H.N.; Mack, W.J.; Henderson, V.W.; Shoupe, D.; Budoff, M.J.; Hwang-Levine, J.; Li, Y.; Feng, M.; Dustin, L.; Kono, N.; et al. Vascular Effects of Early versus Late Postmenopausal Treatment with Estradiol. N. Engl. J. Med. 2016, 374, 1221-1231. [CrossRef]

174. Loomes, R.; Hull, L.; Mandy, W.P.L. What Is the Male-to-Female Ratio in Autism Spectrum Disorder? A Systematic Review and Meta-Analysis. J. Am. Acad. Child Adolesc. Psychiatry 2017, 56, 466-474. [PubMed]

175. Baron-Cohen, S.; Auyeung, B.; Nørgaard-Pedersen, B.; Hougaard, D.M.; Abdallah, M.W.; Melgaard, L.; Cohen, A.S.; Chakrabarti, B.; Ruta, L.; Lombardo, M.V. Elevated fetal steroidogenic activity in autism. Mol. Psychiatry 2015, 20, 369-376. [CrossRef] [PubMed]

176. Crespi, B.J. Oxytocin, testosterone, and human social cognition. Biol. Rev. Camb. Philos. Soc. 2016, 91, 390-408. [CrossRef] [PubMed]

177. Baron-Cohen, S. The extreme male brain theory of autism. Trends Cogn. Sci. 2002, 6, 248-254. [CrossRef]

178. Srivastava, D.P.; Woolfrey, K.M.; Liu, F.; Brandon, N.J.; Penzes, P. Estrogen receptor $B$ activity modulates synaptic signaling and structure. J. Neurosci. Off. J. Soc. Neurosci. 2010, 30, 13454-13460. [CrossRef]

179. Crider, A.; Thakkar, R.; Ahmed, A.O.; Pillai, A. Dysregulation of estrogen receptor beta (ER $\beta$ ), aromatase (CYP19A1), and ER co-activators in the middle frontal gyrus of autism spectrum disorder subjects. Mol. Autism 2014, 5, 46. [CrossRef]

180. Chakrabarti, B.; Dudbridge, F.; Kent, L.; Wheelwright, S.; Hill-Cawthorne, G.; Allison, C.; Banerjee-Basu, S.; Baron-Cohen, S. Genes related to sex steroids, neural growth, and social-emotional behavior are associated with autistic traits, empathy, and Asperger syndrome. Autism Res. Off. J. Int. Soc. Autism Res. 2009, 2, 157-177. [CrossRef]

181. Rucklidge, J.J. Gender differences in attention-deficit/hyperactivity disorder. Psychiatr. Clin. N. Am. 2010, 33, 357-373. [CrossRef]

182. Quinn, P.O. Treating adolescent girls and women with ADHD: Gender-specific issues. J. Clin. Psychol. 2005, 61, 579-587. [CrossRef]

183. Sahin, N.; Altun, H.; Kurutaş, E.B.; Findıklı, E. Evaluation of estrogen and G protein-coupled estrogen receptor 1 (GPER) levels in drug-naïve patients with attention deficit hyperactivity disorder (ADHD). Bosn. J. Basic Med. Sci. 2018, 18, 126-131. [CrossRef]

184. Schug, T.T.; Blawas, A.M.; Gray, K.; Heindel, J.J.; Lawler, C.P. Elucidating the links between endocrine disruptors and neurodevelopment. Endocrinology 2015, 156, 1941-1951. [CrossRef] [PubMed]

185. Matsuda, S.; Matsuzawa, D.; Ishii, D.; Tomizawa, H.; Sutoh, C.; Nakazawa, K.; Amano, K.; Sajiki, J.; Shimizu, E. Effects of perinatal exposure to low dose of bisphenol A on anxiety like behavior and dopamine metabolites in brain. Prog. Neuropsychopharmacol. Biol. Psychiatry 2012, 39, 273-279. [CrossRef] [PubMed]

186. Wilens, T.E. Effects of methylphenidate on the catecholaminergic system in attention-deficit/hyperactivity disorder. J. Clin. Psychopharmacol. 2008, 28 (Suppl. S2), S46-S53. [CrossRef] [PubMed]

187. Casas, M.; Forns, J.; Martínez, D.; Avella-García, C.; Valvi, D.; Ballesteros-Gómez, A.; Luque, N.; Rubio, S.; Julvez, J.; Sunyer, J.; et al. Exposure to bisphenol A during pregnancy and child neuropsychological development in the INMA-Sabadell cohort. Environ. Res. 2015, 142, 671-679. [CrossRef] [PubMed]

188. Rochester, J.R.; Bolden, A.L.; Kwiatkowski, C.F. Prenatal exposure to bisphenol A and hyperactivity in children: A systematic review and meta-analysis. Environ. Int. 2018, 114, 343-356. [CrossRef] [PubMed]

189. McLean, C.P.; Asnaani, A.; Litz, B.T.; Hofmann, S.G. Gender differences in anxiety disorders: Prevalence, course of illness, comorbidity and burden of illness. J. Psychiatr. Res. 2011, 45, 1027-1035. [CrossRef] [PubMed]

190. Hayward, C.; Sanborn, K. Puberty and the emergence of gender differences in psychopathology. J. Adolesc. Health 2002,30 (Suppl. S1), 49-58. [CrossRef]

191. Fındıklı, E.; Camkurt, M.A.; Karaaslan, M.F.; Kurutas, E.B.; Altun, H.; İzci, F.; Fındıklı, H.A.; Kardas, S. Serum levels of G protein-coupled estrogen receptor 1 (GPER1) in drug-naive patients with generalized anxiety disorder. Psychiatry Res. 2016, 244, 312-316. [CrossRef]

192. Zheng, Y.; Wu, M.; Gao, T.; Meng, L.; Ding, X.; Meng, Y.; Jiao, Y.; Luo, P.; He, Z.; Sun, T.; et al. GPER-Deficient Rats Exhibit Lower Serum Corticosterone Level and Increased Anxiety-Like Behavior. Neural Plast. 2020, 2020, 8866187. [CrossRef]

193. Solomon, M.B.; Herman, J.P. Sex differences in psychopathology: Of gonads, adrenals and mental illness. Physiol. Behav. 2009, 97, 250-258. [CrossRef]

194. Dombret, C.; Naulé, L.; Trouillet, A.-C.; Parmentier, C.; Hardin-Pouzet, H.; Mhaouty-Kodja, S. Effects of neural estrogen receptor beta deletion on social and mood-related behaviors and underlying mechanisms in male mice. Sci. Rep. 2020, 10, 6242. [CrossRef] [PubMed]

195. Miller, C.K.; Krentzel, A.A.; Patisaul, H.B.; Meitzen, J. Metabotropic glutamate receptor subtype 5 (mGlu5) is necessary for estradiol mitigation of light-induced anxiety behavior in female rats. Physiol. Behav. 2020, 214, 112770. [CrossRef] [PubMed]

196. Kessler, R.C.; Aguilar-Gaxiola, S.; Alonso, J.; Benjet, C.; Bromet, E.J.; Cardoso, G.; Degenhardt, L.; de Girolamo, G.; Dinolova, R.V.; Ferry, F.; et al. Trauma and PTSD in the WHO World Mental Health Surveys. Eur. J. Psychotraumatol. 2017, 8 (Suppl. S5), 1353383. [CrossRef] [PubMed]

197. Wade, D.; Varker, T.; Kartal, D.; Hetrick, S.; O’Donnell, M.; Forbes, D. Gender difference in outcomes following trauma-focused interventions for posttraumatic stress disorder: Systematic review and meta-analysis. Psychol. Trauma Theory Res. Pract. Policy 2016, 8, 356-364. [CrossRef] 
198. Ney, L.J.; Matthews, A.; Bruno, R.; Felmingham, K.L. Modulation of the endocannabinoid system by sex hormones: Implications for posttraumatic stress disorder. Neurosci. Biobehav. Rev. 2018, 94, 302-320. [CrossRef]

199. Glover, E.M.; Jovanovic, T.; Norrholm, S.D. Estrogen and Extinction of Fear Memories: Implications for Posttraumatic Stress Disorder Treatment. Biol. Psychiatry 2015, 78, 178-185. [CrossRef]

200. Nillni, Y.I.; Pineles, S.L.; Patton, S.C.; Rouse, M.H.; Sawyer, A.T.; Rasmusson, A.M. Menstrual cycle effects on psychological symptoms in women with PTSD. J. Trauma. Stress 2015, 28, 1-7. [CrossRef]

201. Lind, M.J.; Marraccini, M.E.; Sheerin, C.M.; Bountress, K.; Bacanu, S.-A.; Amstadter, A.B.; Nugent, N.R. Association of Posttraumatic Stress Disorder With rs2267735 in the ADCYAP1R1 Gene: A Meta-Analysis. J. Trauma. Stress 2017, 30, 389-398. [CrossRef]

202. Maddox, S.A.; Kilaru, V.; Shin, J.; Jovanovic, T.; Almli, L.M.; Dias, B.G.; Norrholm, S.D.; Fani, N.; Michopoulos, V.; Ding, Z.; et al. Estrogen-dependent association of HDAC4 with fear in female mice and women with PTSD. Mol. Psychiatry 2018, 23, 658-665. [CrossRef]

203. Feng, Y.; Su, M.; Si, Y.J.; Guo, Q.W.; Lin, J.; Cao, T.; Zhang, X.; Fan, M.; Fang, D.Z. Longitudinal interplays of estrogen receptor alpha gene rs9340799 with social-environmental factors on post-traumatic stress disorder in Chinese Han adolescents after Wenchuan earthquake. Am. J. Med. Genet. Part B Neuropsychiatr. Genet. Off. Publ. Int. Soc. Psychiatr. Genet. 2018, 177, 337-345. [CrossRef]

204. Feng, Y.; Lin, J.; Su, M.; Zhang, X.; Fang, D.Z. Interplays of estrogen receptor alpha gene rs2234693 with post-traumatic stress disorder influence serum glucose and lipids profiles in Chinese adolescents. J. Clin. Neurosci. Off. J. Neurosurg. Soc. Australas 2019, 61, 36-43. [CrossRef] [PubMed]

205. Sartin-Tarm, A.; Ross, M.C.; Privatsky, A.A.; Cisler, J.M. Estradiol Modulates Neural and Behavioral Arousal in Women with Posttraumatic Stress Disorder During a Fear Learning and Extinction Task. Biol. Psychiatry Cogn. Neurosci. Neuroimaging 2020, 5 , 1114-1122. [PubMed]

206. Udo, T.; Grilo, C.M. Prevalence and Correlates of DSM-5-Defined Eating Disorders in a Nationally Representative Sample of U.S. Adults. Biol. Psychiatry 2018, 84, 345-354. [CrossRef] [PubMed]

207. Culbert, K.M.; Sinclair, E.B.; Hildebrandt, B.A.; Klump, K.L.; Sisk, C.L. Perinatal testosterone contributes to mid-to-post pubertal sex differences in risk for binge eating in male and female rats. J. Abnorm. Psychol. 2018, 127, 239-250. [CrossRef]

208. Mikhail, M.E.; Culbert, K.M.; Sisk, C.L.; Klump, K.L. Gonadal hormone contributions to individual differences in eating disorder risk. Curr. Opin. Psychiatry 2019, 32, 484-490. [CrossRef]

209. Asarian, L.; Geary, N. Sex differences in the physiology of eating. Am. J. Physiol. Regul. Integr. Comp. Physiol. 2013, 305, R1215-R1267. [CrossRef]

210. Klump, K.L.; Fowler, N.; Mayhall, L.; Sisk, C.L.; Culbert, K.M.; Burt, S.A. Estrogen moderates genetic influences on binge eating during puberty: Disruption of normative processes? J. Abnorm. Psychol. 2018, 127, 458-470. [CrossRef]

211. Lutter, M.; Khan, M.Z.; Satio, K.; Davis, K.C.; Kidder, I.J.; McDaniel, L.; Darbro, B.W.; Pieper, A.A.; Cui, H. The Eating-Disorder Associated HDAC4A778T Mutation Alters Feeding Behaviors in Female Mice. Biol. Psychiatry 2017, 81, 770-777. [CrossRef]

212. McElroy, S.L.; Guerdjikova, A.I.; Mori, N.; Keck, P.E. Psychopharmacologic treatment of eating disorders: Emerging findings. Curr. Psychiatry Rep. 2015, 17, 35. [CrossRef]

213. Brady, K.T.; Randall, C.L. Gender differences in substance use disorders. Psychiatr. Clin. N. Am. 1999, 22, 241-252. [CrossRef]

214. Agabio, R.; Campesi, I.; Pisanu, C.; Gessa, G.L.; Franconi, F. Sex differences in substance use disorders: Focus on side effects. Addict. Biol. 2016, 21, 1030-1042. [CrossRef] [PubMed]

215. Szabo, G. Women and alcoholic liver disease-warning of a silent danger. Nat. Rev. Gastroenterol. Hepatol. 2018, 15, $253-254$. [CrossRef] [PubMed]

216. Martel, M.M.; Eisenlohr-Moul, T.; Roberts, B. Interactive effects of ovarian steroid hormones on alcohol use and binge drinking across the menstrual cycle. J. Abnorm. Psychol. 2017, 126, 1104-1113. [CrossRef] [PubMed]

217. Satta, R.; Hilderbrand, E.R.; Lasek, A.W. Ovarian Hormones Contribute to High Levels of Binge-Like Drinking by Female Mice. Alcohol. Clin. Exp. Res. 2018, 42, 286-294. [CrossRef]

218. Vandegrift, B.J.; Hilderbrand, E.R.; Satta, R.; Tai, R.; He, D.; You, C.; Chen, H.; Xu, P.; Coles, C.; Brodie, M.S.; et al. Estrogen Receptor $\alpha$ Regulates Ethanol Excitation of Ventral Tegmental Area Neurons and Binge Drinking in Female Mice. J. Neurosci. Off. J. Soc. Neurosci. 2020, 40, 5196-5207. [CrossRef] 